\title{
The Untapped Potential: Understanding Algal Sulfated Polysaccharides and their Applications: A review
}

\author{
Anup Kumar Prusty1 and V. L. Sirisha1*
\#1 Department of Biology, UM-DAE Centre for Excellence in Basic Sciences, Kalina
campus, Santacruz (E), Mumbai, 400098, India.
Corresponding author: *sirisha@ @bs.ac.in
}

\begin{abstract}
Natural polymers are among the most in-demand biomaterials for the biomedical industry. The reasons for this are not hard to see - their biodegradability and biocompatibility. What makes them particularly of interest is the biological and chemical diversity that's found in the marine environment. And this diversity only continues to grow in deeper waters. At the same time, these materials are considered a low-risk for humans. More specifically, sulfated polysaccharides that abound in different algae species in the marine environment have been shown to offer a variety of health benefits. Terrestrial plans do not have equivalents for such polysaccharides, which represent mammalian glycosaminoglycans in their biological and chemical properties. These factors are driving growing interest in health-related applications of sulfated polysaccharides. Marine algae sulfated polysaccharides, and their biological applications are the focus of this review.
\end{abstract}

Keywords:Biological applications, Carrageenans, Fucoidan, Laminarin, Seaweed, Sulfated polysaccharides, Ulvans.

\section{INTRODUCTION}

Polysaccharides are water soluble, functionally active and biodegradable in nature. And these very characteristics are helping them emerge as a key ingredient in biomedical applications. Their sources are varied and include marine organisms, agricultural produce and microorganisms. Given the fact that $70 \%$ of earth's surface is water, the rich diversity of marine organisms acts as a highly useful source of polysaccharides, antioxidants, essential minerals, vitamins, enzymes, bioactive peptides and polyunsaturated fatty acids [1-2]. 15\% of the ocean's total carbon storage is made of marine algae that are a rich source of structurally diverse bioactive compounds. It has been observed through research on such organisms that they are a very good source of novel bioactive substances and compounds of marine algal origin. Some of the characteristics that they exhibit include antioxidant, anticancer, antiviral, immunomodulating, antiulcer, anti-inflammatory, antiparasitic, antilipemic, anti-angiogenic, and anticoagulant activities [3-4].

Marine algae are a rich source of polysaccharides. These include mucopolysaccharides, cell wall structural polysaccharides and storage polysaccharides [5-6]. All of them are polymers of monosaccharides (simple sugars). They have a variety of commercial applications in a range of products such as gelling agents, food, beverages, thickeners, emulsifiers, among others [7-9]. Consider, for instance, that seaweed species contain polysaccharide concentrations that range from 4-76\% of the dry weight [10]. Some species such as Ascophyllum, Porphyra, Palmaria and Ulva show high concentration of polysaccharide content (up to $65 \%$ ). 
Cell wall polysaccharides are largely made up of cellulose, hemicellulose and neutral polysaccharides. This composition gives them the ability to physically support the thallus in water. Moreover, storage polysaccharides and cell walls are species-specific and they are available in abundance as reported by Kraan [10]. In green seaweeds, the principal polysaccharides are sulphuric acid polysaccharides and ulvans. In red seaweeds, they include xylans, water-soluble sulfated galactan, mucopolysaccharides, floridean starch (amylopectin like glucan), and carrageenans [6, 10]. In brown seaweeds, the primary polysaccharides include fucodian, sargassan, laminarin and alginic acid. It has also been observed that there are seasonal variations in content of both species-specific and total polysaccharides. Beyond these, there are several other polysaccharides that are present in, and can be utilized from seaweed.

Seaweed species such as marine macroalgae are used as food as a result of their potent health benefits (Table 1). Seaweeds have very high carbohydrate content, but very low lipid and fat content. Most of the carbohydrates are dietary fibres which are not digested by the human body. However, as dietary fibres make a favorable intestinal environment, they are good for human health [11]. Most of the carbohydrates present in seaweed cell wall are sulfated polysaccharides. These sulfated polysaccharides are used as additives in food industry, because of their efficient rheological properties. Recently, they are also showing promising biological activities as antioxidant, antiviral, anticancer, anti-inflammatory, anticoagulant etc and hence help them find applications and relevance in a variety of industries such as cosmetic/cosmeceutical, nutraceutical/functional food and pharmaceutical industries.

Table 1: Aquaculture produced seaweeds benefits (Adapted from [10])

\begin{tabular}{|c|c|c|c|}
\hline S.No & Class & Genus & Uses \\
\hline 1 & Chlorophyta & Monostroma & Edible, human food \\
\hline & & Enteromorpha & Edible, human food \\
\hline 2 & Phaeophyta & Laminaria & Alginates, edible, human food \\
\hline & & Undaria & Edible, human food \\
\hline 3 & Rhodophyta & Cladosiphon & Edible, human food \\
\hline & & Asparagopsis & Medical applications \\
\hline & & Gelidiella & Agar, food and medical \\
\hline & & Gelidium & Agar, food and medical \\
\hline & & Gracilaria & agar, food and medical \\
\hline & & Pterocladia & agar, food and medical \\
\hline & & Chondrus & agar, food and medical \\
\hline & & Eucheuma & carrageenan, human food \\
\hline & & Kappaphycus & carrageenan, human food \\
\hline & & Gigartina & carrageenan, human food \\
\hline & & Hypnea & carrageenan, human food \\
\hline & & Iridaea & carrageenan, human food \\
\hline & & Palmaria & human and animal feed \\
\hline & & Porphyra & human food \\
\hline
\end{tabular}

Sulfated Polysaccharides in different algae: Algal cell wall contains intracellular sulfated polysaccharides which have been recognized to offer a protective barrier against pathogen. This is in addition to their role of providing cell adhesion and interactions in animals. This dual protective and supportive roles are known in algae [12]. In the case of microalgae, sulfated polysaccharides are known to act as efficient ingredients for functional, 
cosmeceutical, pharmaceutical and nutraceutical applications because of their antilipidemic, antimalarial, antiparasitic, antiviral, antioxidant, anti-inflammatory, anti-thrombotic, anticoagulant properties and high nutritional value [12-16]. In brown algae the major form of sulfated polysaccharides are fucans and alginates. In the case of red algae the major forms of sulfated polysaccharides are agaran and carrageenans. In green algae they include heteroglycuronan, ulvans and sulfated galactans [14, 17]. A brief description of these polysaccharides, their structure and applications were listed in Table 2 and discussed subsequently.

Table2. Sulfated Polysaccharides of brown, red and green algae

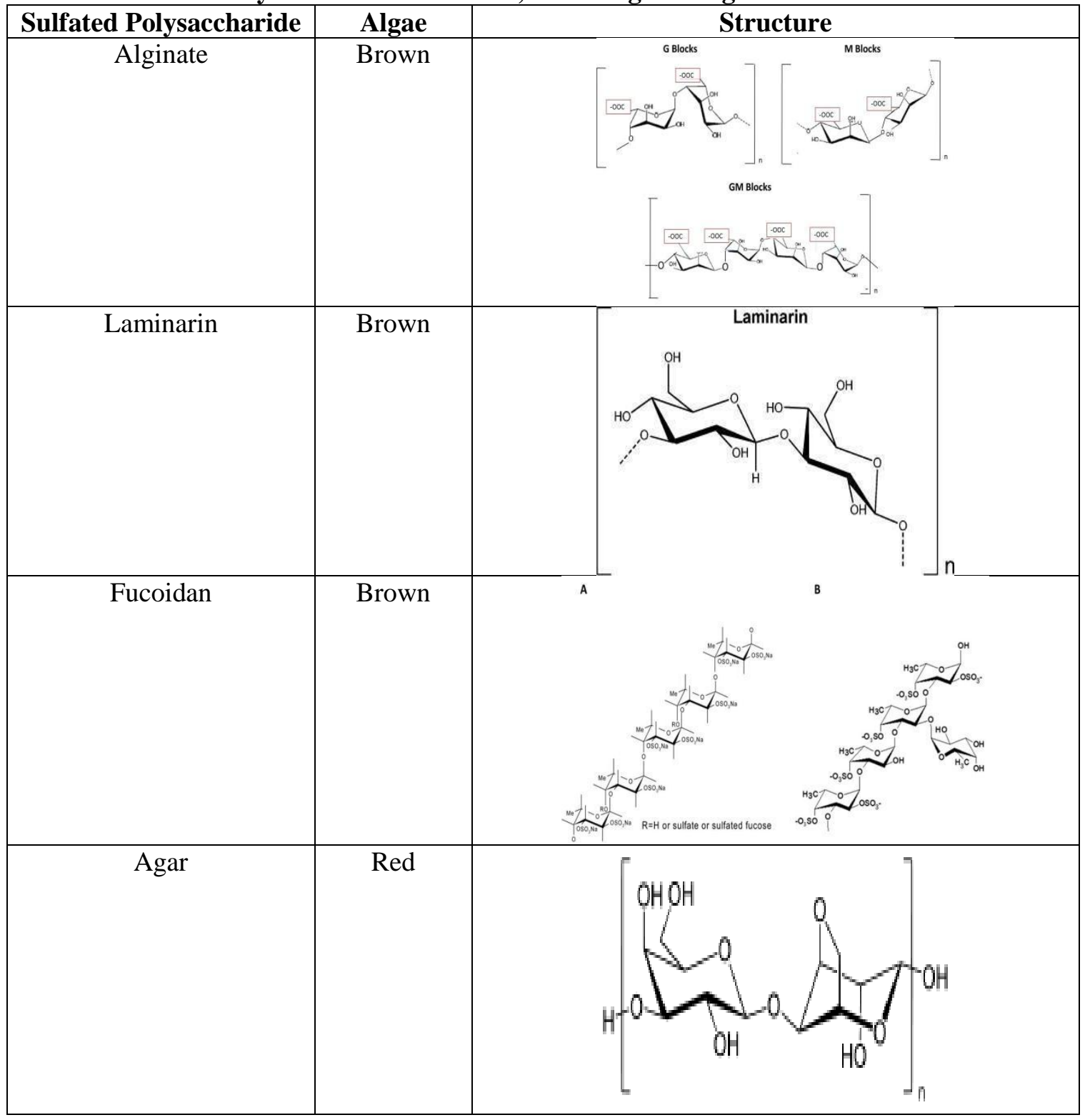




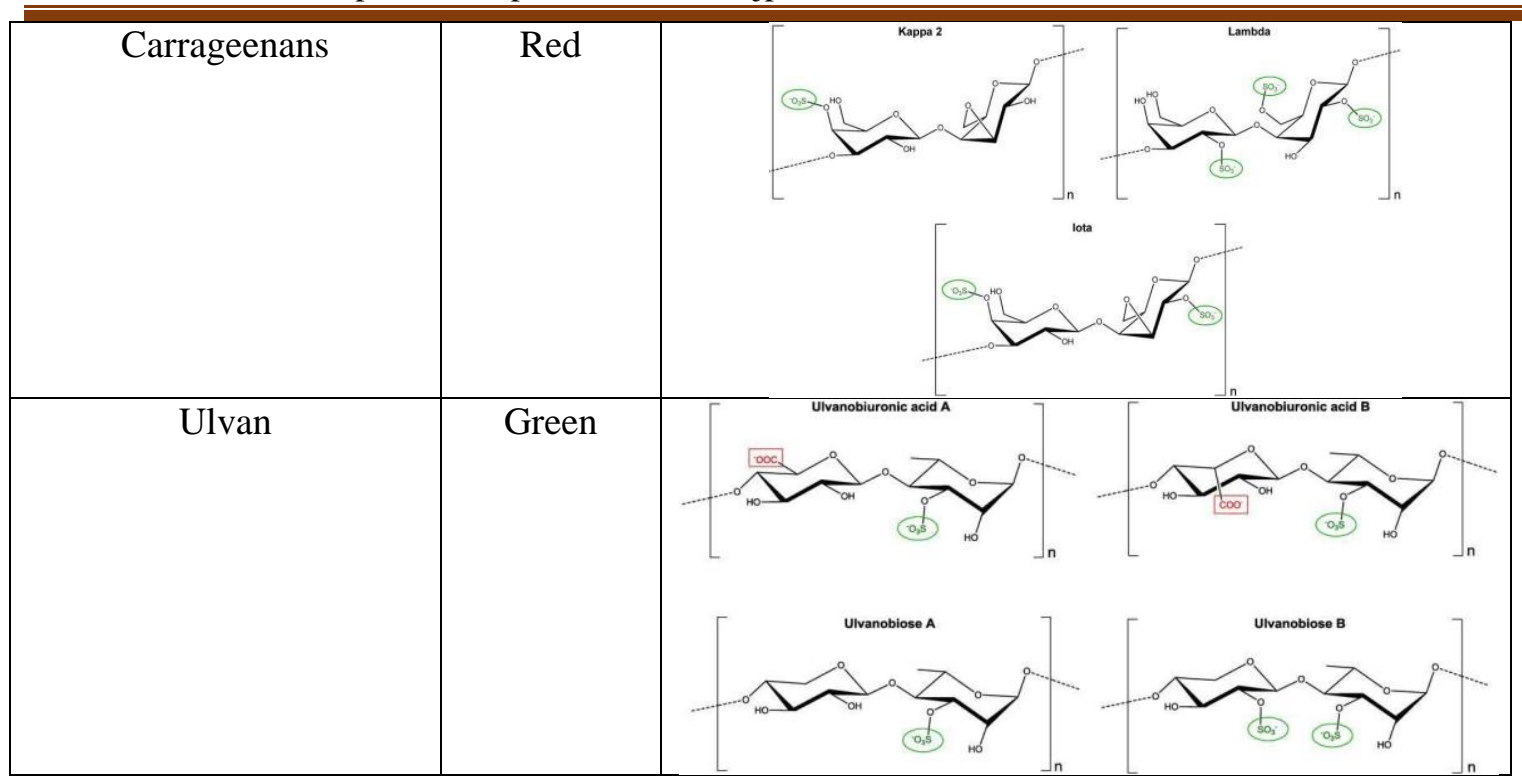

Agar: Agar is a polysaccharides mixture made up of agarose and agaropectin. It has functional and structural properties similar to carrageenans. It has also been observed in earlier research that Gelidium spp. and Gracilaria spp agar extract melts and gels at very high temperature as compared to carrageenans [18-20]. This enables agar to be used in pastry glazes and fillings to be used before a pastry is baked without melting in the oven. While carrageenan is the preferred water binder or texturing agent in processed meats, agar is used in the gelatine replacement market for canned meats and aspics. The texture of agar in fruit jellies, preferred by some, also results in a niche market. In biotechnology for gel electrophoresis, agarose, which is sulphate free form of agar is used for separation of biomolecules.

Carrageenans: Carrageenans are a key constituent of red seaweed cell wall. They are hydrophilic polysaccharides and represent 30-75 \% of the algal dry weight [21]. They are composed of linear polysaccharide chains with sulphate half-esters linked to the sugar unit. Carrageenans remain stable across a range of $\mathrm{pH}$ and are a water soluble viscous solution. Chemically these hydrophilic colloids are sulphated galactans with varying sulphate content. This sulphate content ranges from $15-40 \%$ [22]. The primary structure consists of alternating $\beta(1-4)$ and $\alpha(1-3)$ sequences attached to D-galactose residues [23], which in polymers of molecular weight varying from 105-106 kDa [24-25]. Kappa (k), iota (i), and lambda (1) are the three main commercially relevant families of carrageenans. They are based on the number and position of sulphate group in the repeating galactose units. Their main characteristics are summed up in Table 3. Structurally, kappa carrageenan is made up of a D-galactose, sulfated in C4 linked to anhydrogalactose, whereas lambda carrageenan is constituted by a Dgalactose sulphated in C2 linked to a D-galactose sulfated in C2 and C6, and iota carrageenan is formed by a galactose sulphated in $\mathrm{C} 4$ linked to an anhydrogalactose sulphated in $\mathrm{C} 2$. The sulphate groups in the carrageenans results in their chemical reactivity. Their structural diversity opens up a wide array of applications [26-27]. More specifically, their usage is being explored in the biomedical industry [28-29]. The reactivity of carrageenans with the milk protein casein makes it significant in the dairy industry [30-31]. Carrageenans are also used for bioremediation owing to their heavy metal binding property [32-33]. They also have the unique ability to control the texture of any formulation of polyols because of their 
interaction with polyols [34]. They are used in a variety of industrial applications such as emulsifying, gelling, thickeners and stabilizing agents. They are also used in processed meat [26, 35], salad dressings, dairy industry [36], personal care products [37]and as an alternative for gelatin in pharmaceutical formulations [38-39].

Table 3: Properties and structure of Kappa, Iota and Lambda carrageenans ([194, 195])

\begin{tabular}{|c|c|c|c|}
\hline Properties & Kappa Carrageenans & Iota carrageenans & Lambda Carrageenans \\
\hline Ionic gel formation & Gels with potassium salts & Gels with calcium salts & No gel formation \\
\hline Gel texture & Brittle with some syneresis & Elastic with no syneresis & No syneresis \\
\hline Freeze/Thaw stability & No & Freez-thaw stable & Freeze-thaw stable \\
\hline Viscosity & Low thixotropic & High,medium thixotropic & $\begin{array}{l}\text { High, medium thixotropic; } \\
\text { forms highly viscous } \\
\text { solutions }\end{array}$ \\
\hline Solubility in water & $\begin{array}{l}\text { Completely soluble in hot } \\
\text { water, partially in cold } \\
\text { water }\end{array}$ & $\begin{array}{l}\text { Completely soluble in hot } \\
\text { water }\end{array}$ & $\begin{array}{l}\text { Completely soluble in hot } \\
\text { water, partially in cold } \\
\text { water }\end{array}$ \\
\hline $\begin{array}{l}\text { Synergism with other } \\
\text { gums }\end{array}$ & $\begin{array}{l}\text { Synergestic with locust } \\
\text { bean gum }\end{array}$ & No & No \\
\hline Acid stability & $\begin{array}{l}>\mathrm{pH} 3.8, \text { neutraland } \\
\text { alkaline } \mathrm{pH}\end{array}$ & $\begin{array}{l}>\mathrm{pH} 3.8 \text {, neutral and } \\
\text { alkaline } \mathrm{pH}\end{array}$ & - \\
\hline Structure & $\begin{array}{lll}7 & 1 \\
\mathrm{H} & \mathrm{H}\end{array}$ & 1-carrageenan & $\mathrm{OH}_{\mathrm{CH}_{2} \mathrm{OH}} \mathrm{O}$ \\
\hline
\end{tabular}

Ulvans: Ulvans constitute $8-29 \%$ of algal dry weight and are a major ingredient of green seaweed cell walls [40]. Rhamnose, xylose, iduronic acid, glucose, glucuronic acid and sulphate are its main constituents. It also has smaller amounts of arabinose, galactose and mannose. Its structure consists of a central backbone of disaccharide units formed by an Lrhamnose 3-sulphate linked to: (1) a D-glucoronic acid residue (ulvabiouronic acid unit A), (2) a L- iduronic acid residue (ulvabiouronic acid unit B), (3) a D-xylose 4-sulphate residue (Ulvabiose unit A), (4) a D-xylose residue (Ulvabiose unit B). It has an average molecular weight of $189-8,200 \mathrm{kDa}$ [41]. The two major identified types of ulvans are water soluble ulvan and insoluble cellulose-like material. Various monosaccharide, disaccharide and oligoulvans with varied molecular weights can be produced by applying chemical and physical reactions [42-44]. Despite their chemical variability, certainbiological effects are common. Sugar composition, molecular weight, and sulphate content are the main determinants of expression of these biological activities. The bioactivity also dependant on species, genus and environmental factors. Green algae sulfated polysaccharides have these biological properties, one could translate them into applications with pharmacological and medical relevance and also in those areas which are as challenging as regenerative medicine.

Alginates: The brown algal (Phaeophyceae) cell wall is largely made of alginate salts and alginic acid. They are largely found in coastal waters around the world [9]. The global market for alginate is valued at $\$ 318 \mathrm{Mn}$ at a production of roughly 26,500 tons annually. The acid form of alginate is a linear polyuronic acid called alginic acid. The salt form that is present in 
all the brown seaweeds comprises upto $40-47 \%$ of the dry weight of algal biomass [45, 18]. Structurally Alginate is a high molecular weight $(\sim 200-500 \times 103 \mathrm{~g} / \mathrm{mol})$ polyuronic acid composed of two types of uronic acids distributed as blocks of guluronic acid (GulA or "G") or mannuronic acid (ManA or "M") as well as heteropolymeric mixed sequences (GulAManA, usually alternating). Often commercial alginate is characterized by its "M: G" ratio.

Alginate is known to be non-toxic, biocompatible, non-toxic, non-allergic and biodegradable in nature. It is both a biopolymer and a polyelectrolyte. At low $\mathrm{pH}$, alginate can form a physical gel through hydrogen bonding. With ionic interactions with divalent and trivalent ions it can act as cross linkers between adjacent polymer chains. Chemical modifications of alginate on its hydroxyl and carboxyl groups result in obtaining new biomaterials. They can be used in controlled drug delivery, cell immobilisation, and tissue engineering [46-47]. There is active ongoing research to improve neo-cartilage or neo-bone formation by transplanting chondrocytes and osteoblasts using customized alginate hydrogels. There are already various grades of alginate available for specific applications. A variety of in vivo and in vitro studies have clearly proved the beneficial uses of such modified alginate gels as biomaterials [48]. They have also found application in paper, cardboard, pharmaceuticals, processed foods and cosmetic creams [49].

Fucoidan: Fucoidan represent around 5-20\% of algae dry weight [50]. They are mainly found in the brown seaweed cell walls [51]. There are largely composed of sulphated Lfucose with less than $10 \%$ of other monosaccharides. It is a ramified sulphated polysaccharide constituted by a central backbone of fucose sulphated in C2 and/or C4 position. Fucans from Ascophyllum nodosum and Fucus vesiculosus are constituted by disaccharide units of fucose sulphated in C2 linked to a fucose sulphated in C2 and C4 [52]. The Lessonia vadosaare, chorda filum fucans are obtained by sulfation of fucons at $\mathrm{C} 4$ position which is linked to fucose residues sulfated at C2 and C4 [53]. The molecular weight of fucoidan vary from $12-950 \mathrm{kDa}$ [54]. Their rheological properties coupled with solubility see them playing a key role in a wide variety of applications [55].

Some of the application areas of fucoidan as reported earlier include food (cholesterol reducer, sports beverage, processed meat products, dietetic fibers and functional fibers); cosmetic (hair hydration, skin exfoliation, acne treatment and tooth paste); and biopharmaceutical (antiviral, immunologic, and anticoagulant) [56-58]. It has also been shown through epidemiological studies such as those performed by Kim and co-workers [59] that fucoidan has anti-aging, skin protectant and antioxidant properties. In recent years, fucoidan applications have been found in the areas of nanomedicine, drug delivery and tissue engineering.

Laminarin: The primary storage polysaccharide in brown seaweed is laminarin. It is a glucan, built up from (1-3)- and (1- 6)- $\beta$-glucose residues and is a linear polysaccharide, with a $\beta(1-3): \beta(1-6)$ ratio of around 3:1. It typically constitutes around $25 \%$ of algal dry weight (O'Sullivan et al. 2010). While the molecular weight can differ based on the type of laminarin, whether it is a G-type laminarin which has the terminal glucose residue or M-type laminarin which has a mannitol residue, it has an average molecular weight of $5000 \mathrm{kDa}$ [55, 60]. The content of laminarin can vary seasonally based on the habitat. It can reach up to $32 \%$ of the dry weight. Laminarins have been used as a substratum for prebiotic bacteria [61], as an antitumor agent, safe surgical dusting powder and also as an anticoagulant [62]. It finds most application in the pharmaceutical and medical industries.

Immense potential of bioactive algal polysaccharides: Algal polysaccharides are a wide group of bioactive compounds. They have been used for a diverse range of commercial 
applications. Fucoidans, carrageenans, alginates, agars and ulvans are the economically important seaweed products that are used in various industries including the food and pharmaceuticals [63]. In recent years because of their chemical properties and useful biological effects, algal polysaccharides have been widely investigated. Most of them carry sulphate groups. There is a positive correlation between the structural requirements (composition, position of sulphate group, extent of sulphation of sulfated polysaccharides and their biological activities like antithrombotic, antioxidant, anticoagulant, antiviral and anticancer activities etc [64]. The key biological activities that have been reported for algal sulfated polysaccharides are captured in Table 4. Their applications are categorized in two based on the industry which they were targeted at such as:

a) Biomedical Applications

b) Biotechnological applications

Their current knowledge regarding their mode of action and the structural requirements necessary to enhance these effects are discussed further.

\section{Biomedical applications of sulfated polysaccharides:}

Antioxidant activities:Algal sulfated polysaccharides have been reported to have significant antioxidant potential [65-71]. In vitro experiments showed that fucoidan is a promising natural antioxidant with considerable antioxidant activity. Marine algae such as Porphyra haitanesis [72], Ulva pertusa [73-74], Fucus vesiculosus [66], Laminaria japonica [75] and Ecklonia kurome [76] have significant amount of sulfated polysaccharides that possess antioxidant activity. There are few reports showing positive correlation between the structural features and antioxidant activity of sulfated polysaccharides from marine algae. The antioxidant activity of fucoidan was found to be more when compared to fucan. This is mainly depended on the molecular weight of the polysaccharides and on the sulphate content ratio [77]. Fucoidan has the potential to prevent free radical mediated diseases like Alzheimer's, aging process etc. Earlier, L. japonica, a commercially important algae species in China was used to extract fucoidan. Through anion-exchange column chromatography, three sulfated polysaccharide fractions were successfully isolated. Their antioxidant activities were investigated using in vitro systems, including superoxide and hydroxyl radical scavenging activity, reducing power and chelating ability [77]. It was found that all the fractions were more effective than the unprocessed fucoidan. Additionally, fucoidan (homofucan) from $F$. vesiculosus and fucans (heterofucans) from Padina gymnospora found to inhibit the formation of hydroxyl and superoxide radicals [67]. Moreover, fucans from $F$. vesiculosus exhibited considerable ferric reducing/antioxidant power [66] and superoxide radical scavenging ability [67]. Fucan fractions from $L$. japonica also showed significant antioxidant capabilities in superoxide radical and hydroxyl radical scavenging assays [68, 70,78]. Superoxide radical scavenging activity correlated positively with the sulphate content of the polysaccharide fractions [67, 70]. Antioxidant properties of carrageenans [67] and ulvans [79] also appeared related to sulphate content. In the latter study, high sulphate content derivatives of ulvan showed improved antioxidant activities [79]. Interestingly, metal chelating, free radical and hydroxyl radical scavenging activities of fucan fractions were directly correlated to their sulphate content/fucose ratio [70].

Antilipidemic activities:In hyperlipidemic animal models, algal sulfated polysaccharides exert lipid-lowering and other beneficial properties [80-82]. It is reported that, in triton-inducedhyperlipidemic rats, an extract from $F$. vesiculosus, effectively decreased the elevation in serum triglyceride and total cholesterol levels in a dose-dependent manner. When rats fed with high cholesterol diet for 21 days supplemented with ulvan from $U$. pertusa, it led to 
reduced total cholesterol and LDL-cholesterol in serum with no significant alteration in serum triglycerides [82]. However, when low molecular weight ulvan was fed to the rats, its effect was altered. For example, lower molecular weight ulvan derivatives with intrinsic viscosity did not reduce serum cholesterol but did normalize the hypertriglyceridemia of these animals and raised HDL-cholesterol. The basic mechanisms of these actions remained elusive. But, it does not appear to involve bile acid sequestration, as ulvan and its lower molecular weight derivatives increased bile excretion to a similar extent. Similarly, fucoidan isolated from L. japonica when given to hyperlipidemic rat model, reduced serum total and LDL-cholesterol and triglycerides and raised HDL-cholesterol [81]. The treatment also elevated the activities of lipoprotein lipase (LPL), hepatic lipase (HL) and lecithin cholesterol acyltransferase (LCAT) in serum. These changes in enzyme activities could be the result of fucoidan treatment or an indirect effect associated with improvement in lipid profile. These data clearly show that fucoidan and other algal sulfated polysaccharides may influence LPL and HL through interaction with well-characterized heparin-binding sites on these enzymes.

Algal sulfated polysaccharides show promising effects in addressing the hyperlipidemia associated with certain drug toxicities. For example, in acetaminopheninduced toxic hepatitis fucans from $S$. polycystum showed significant preventive effects on the elevation of cholesterol and triglycerides in serum and liver tissue [83]. Treatment also improved overall histological appearance of the liver and partially reversed the reduction in hepatic LCAT and HL. Similarly, in cyclosporine A-induced nephrotoxicity, when a sulfated polysaccharide from $S$. wightii was given, itreduced hyperlipidemia and normalized LPL and LCAT in plasma [84]. Furthermore, treatment with sulfated polysaccharide normalized excretion of urea, uric acid, and creatinine. In addition, the susceptibility of LDL to oxidation was reduced, demonstrating that the antioxidant activity of the sulfated polysaccharide was also playing a role and may contribute to its renoprotective activity.

Antiviral activities:Algal polysaccharides were found to have the ability to inhibit the replication of many enveloped viruses such as human immunodeficiency virus (HIV), dengue virus, herpes simplex virus (HSV), respiratory syncytial virus, and human cytomegalovirus [85-88]. More than 50 years ago, the seaweed extracts showed antiviral activities by protecting chicken embryos against influenza B and mumps [89]. Subsequently it was reported the HSV was inhibited in leukocyte cultures by heparin,this is hypothesized to be due to electrostatic interference of cell surfaces with viral attachment [90]. This research paved a way to check various polyanionic substances including seaweed sulfated polysaccharides for antiviral effects. In recent years antiviral effects of algal polysaccharides has grown significantly because of their direct effect on viral replication. This effect is mainly by polysaccharides specific structural qualities and not by nonspecific interactions $[85,91]$. It was reported earlier that a fucan from Cladosiphon okamuranus, which is made up of glucuronic acid and sulfated fucose units substantially inhibited dengue virus type 2 (DENV-2) in BHK-21 cells. However the fucan showed very little effect on the other three serotypes of the virus [92]. It was observed that there was a positive correlation between antiviral activity and sulphation of the fucan. Interestingly it was shown that the antiviral property was inhibited by carboxyl-reduction of the glucuronic acids to glucose units. Structural analysis of the four stereotypes revealed that the arginine-323 in DENV-2, which is proximal to the putative heparin binding site, was crucial for the interaction with the fucan. Similarly in vero cells, DENV-2 multiplication was inhibited by two polysaccharides, one was a galactan from Cryptonemia crenulata and another was carrageenan from Gymnogongrus griffithsiae [93-94]. Their effects were less effective against DENV-3 and 
DENV-4 and were completely ineffective against DENV-1 infection [94]. In case of DENV2 , these polysaccharides were found to interfere with its adsorption and internalization with the cells. They were only effective if added immediately after infection or along with the virus. Moreover, virus multiplication was not inhibited when the normal viral entry process was bypassed by DENV-2 RNA transfection into the cells [93].

Fucoidan also showed antiviral activities by inhibiting viral sorption so as to prevent viral-induced syncytium formation [95]. For antiviral and antiherpetic activity of fucoidan, sulphate is necessary and the sulphate located C-4 of (1-3)-linked fucopyranosyl units found to be playing an important role [95]. The red seaweed Sebdenia polydactyla sulfated xylomannans prevented the propagation of HSV-1 in Vero cells [91]. However, its antiviral activity was inhibited by desulphation of the xylomannan and, contrarily, activity was significantly enhanced by oversulfated derivatives. In Sargassum latifolium,asulfated polysaccharide which has greater sulphate ester content and molecular weight compared to the other fractions inhibited the growth of HSV-1 in the plaque assay [96]. Similarly various sulfated polysaccharides (galactofucans, fucans and galactans) from brown and red seaweeds differing in structural features (molecular weight and sulfation level) were shown to inhibit HSV-1 and HSV-2 infection [97]. This clearly support the view that, the antiviral activity of sulfated polysaccharides is due to a complex reciprocation of structural features [87, 91]. They also exhibited an ability to inactivate HSV-2 directly through incubation with the virus. This activity has importance as it is associated with augmentation of antiviral activity in vivo [98].

It has been reported recently that the carrageenan gels from $C$. crispus may avoid the transmission of the HIV virus as well as other STD viruses such as gonorrhoea, herpes simplex virus (HSV) and genital warts, [85, 88, 99-101]. It was also showed that by using condoms lubricated with carrageenan-based gels, sexual transmission of HPV (human papillomavirus) which cause cervical cancer and genital warts can be prevented..In vitro studies showed that carrageenans exhibited a 1000 fold higher IC50s values with herpes simplex virus and HIV-1 infection than genital HPVs[85,88]. Also, reported that a carrageenan-based vaginal microbicide known as carraguard, has shown the ability to block HIV and other STD's in vitro.

Anticoagulant activities:Polysaccharides that are most widely studied for their heparin-like anticoagulant activity include marine sulfated polysaccharides such as fucoidans and other fucans of brown seaweeds. Springer and his colleagues for the first time isolated fucoidan from Fucus vesiculosus. They were also the first to observe its property of inhibiting fibrin clot formation and antithrombin activity [102-103]. Post that, multiple studies on fucans from a variety of seaweeds have showed the anticoagulant and antithrombotic activities [104-106]. Given the fact that fucoidan is produced from plant material and is less likely to contain infectious agents, it has been proposed as a replacement to the injectable anticoagulant heparin [51]. On injecting rats with $300 \mathrm{mg} / \mathrm{kg}$ body weight per day fucoidan, no major toxicological changes were observed. On the other hand, when concentrations were increased $3 \mathrm{x}$, significantly prolonged blood-clotting times were observed [107]. The basis for these activities has largely remained elusive. However, various investigations suggest that fucoidan activates the thrombin inhibitors such as e.g antithrombin and heparin cofactor II, which inhibit thrombin either directly or indirectly [108-111]. Cumashi et al. [112] reported that 5 out of 10 fucans isolated from 10 brown seaweeds extended the clotting time of human plasma via thrombin-induced platelet aggregation. This is suggestive of a direct action of certain fucans on thrombin. At the same time, an inhibitory action of thrombin binding to its 
receptors on platelets cannot be ruled out. It is reported that the sulfated polysaccharides bioactivity mainly depends on various structural requirements such as molecular weight, sulphate ester content, amount of sulphation, sugar composition and also on the position of sulphate groups on the sugar backbone [113-115]. It was showed that fucoidan needs a long sugar chain in order to be able to bind to thrombin and exhibit anticoagulant activity. Native fucoidan having a molecular weight of $320 \mathrm{kDa}$ showed a good anticoagulant activity as compared to a smaller depolymerised fraction with molecular weight of $32 \mathrm{kDa}$ [105]. The sulfated polysaccharides fraction from Ecklonia kurome that were found to containhigher fucose content and sulphate groups, coincided with enhanced anticoagulant activities [113]. It has also been reported that the amount of sulphate content is directly proportional to the anticoagulant activity. It was found that fucans that have higher ratio of total sugar-sulphate possessed significant activity [114,116]. Pomin and colleagues [115] found that linear sulfated fucan required significantly longer chains than mammalian glycosaminoglycans. They have also shown that reducing the molecular size by selective cleavage resulted in significant reduction of its effect on thrombin inactivation mediated by heparin cofactor II. This can be largely attributed to the fact that the lower molecular weight fucans unlike the native (full length) fucan are ineffective in facilitating the heparin cofactor II interaction with thrombin [115]. The correlation between sulphate group location on the sugar residues and anticoagulant activity has been reported by Chevolot and co-workers [52]. Their studies conclusive established the role of 2-O-sulfated and 2,3-Odisulphated fucose residues for the anticoagulant activity of fucoidan from Ascophyllum nodosum.

Ulvan-like sulfated polysaccharides obtained from green algae, also possess anticoagulant activities [99, 117-120]. Sulfated polysaccharides from 23 green algae species were tested for anticoagulant activity. The results showed that sulphated polysaccharide from Monostroma nitidum containing high sugar (rhamnose) content was found to be more significant than standard heparin obtained from the purified version [120].

Multiple sulfated polysaccharides from red seaweeds have also shown to have potent anticoagulant activities [99, 121-123]. In $\mathrm{B}$. occidentalis it is observed that, a 2, 3-di-Osulfated D-galactan exhibited anticoagulant activity. This is comparable to heparin and is due to inhibition of thrombin and factor X. Its activity was much more pronounced than similar sulfated galactans from invertebrate sources that had only one sulphate per galactose residue [121]. It was also observed that a polysaccharide chain but with lower amounts of 2, 3-di-Osulfated D-galactose in Gelidium crinale, was less potent in a clotting time assay when compared to $B$. occidentalis [123]. The mechanism of anticoagulant activity showed by these two sulfated polysaccharides was found to be same. What was different though, was that, when antithrombin was replaced with heparin cofactor II, the sulfated galactan from $B$. occidentalis was more inhibitory than that from $G$. Crinale. In cases where Factor Xa was the target protease, the sulfated galactan from $G$. crinale was found to be a much more efficient anticoagulant than that from $B$. occidentalis. These findings clearly show that the distribution of 2,3-di-sulfated galactose along the polysaccharide chain modulates the interaction of the polysaccharides with specific proteases in the coagulation system.

Antithrombotic activities:Heparin is widely used to prevent venous thrombosis and for treatment of other thrombotic disorders due to its inhibition of thrombin and other enzymes in the coagulation system. Researchers have explored approaches to reducing the anticoagulant activities while enhancing its anti-thrombotic activities of heparin. This includes chemical modification and fractionation of native heparin to lower molecular forms. This is crucial to avoid the side-effect of heparin like bleeding [124-126]. At the same time, development of 
antithrombotic agents from algal polysaccharides holds several advantages as it bypasses the potential for contamination with viruses or prions unlike commercial heparins, which are obtained generally from bovine and pig intestine. Also, algal sulfated polysaccharides with highly specific targets and/or activities can find applications corresponding to heparin [124]. One route to achieving this is to develop low molecular weight (LMW) fucoidans [127]. Millet et al [127] reported that in a rabbit model of venous thrombosis, injecting LMW fraction of Fucoidan $(\sim 8,000 \mathrm{Da})$ derived from A. nodosum, a reduced mean thrombus weight by $80 \%$ vs. control saline injection. This LMW fucoidan and related derivatives [128] are favourable as they show lower effects in coagulation tests. It has also been reported that in Spatoglossum schoeder (brown seaweed), a sulfated galactofucan, has showed high antithrombotic activity in a rat model of venous thrombosis [67]. Post eight hours injection, the in vivo action of this sulfated galactofucan showed slow progression and maximal effectiveness. This is unlike heparin which produces a rapid but transient antithrombotic effect. In vitro tests on endothelial cells showed that the galactofucan activates heparan sulphate production. This indicated that its delayed action in vivo is due to the need of heparan sulphate accumulation on the surface of the blood vessels. High sulfation levels, coupled with lack of significant anticoagulation activity make the galactofucan a suitable candidate as an antithrombotic agent [67].

Carrageenans also exhibit anticoagulant activity and inhibit platelet aggregation [129131]. However, in comparison to heparin, the most active carrageenan has approximately one fifteenth activity [129]. Later on Sen et al. [132] isolated a sulfated galactan from Grateloupa indica, exhibited anticoagulant activity as significant as heparin [132]. It was found that the primary reason for the anticoagulant activity of carrageenan is because of its antithrombotic property. $\lambda$-carrageenan showed because of its high sulphate content showed greater antithrombotic activity than $\kappa$-carrageenan. Similarly $\lambda$-carrageenan of Phyllophora brodiaei gave the highest blood anti-coagulant activity [132].

In addition to carrageenans, Laminaria showed the presence of anticoagulant activity [99] (Shanmugam \& Mody 2000). However, laminarin showed anticoagulant activity only after structural modifications. These include sulphation, reduction or oxidation. Anticoagulant activity was improved by increasing the degree of sulphation [99].

Immunoinflammatory activities:The immunomodulatory activity of sulfated polysaccharides helps in triggering the immune response or in controlling immune cell activity to reduce associated negative effects such as inflammation [133]. They have the potential to interfere with the migration of leukocytes to sites of inflammation, making them the promising antiinflammatory agents. For instance, it is reported that in a rabbit model of bacterial meningitis, intravenous infusion of fucoidan significantly reduced leukocyte rolling [134].Similarly, intravenous addition of fucoidan in a dose-dependent manner reduced peritoneal inflammation in a rat model, moreover leukocyte recruitment to peritoneum was also observed [135]. These effects are due to the binding of fucoidan to cell adhesion molecules like L- and P-selectins, which are required in the recruitment process. Earlier reports showed that in mice which are in the early stages of Staphylococcus aureus-triggered arthritis, when treated with fucoidan showed less severe symptoms, [136]. Additionally, mice showed reduced hypersensitivity reactions when injected with fucoidan before hapten challenge [137]. Furthermore,fucoidan also reduced recruitment of leukocytes into cerebrospinal fluid in a meningitis model [134] as is IL-1 (interleukin-1) production in a similar model [138]. Algal sulfated polysaccharides also reported to inhibit tissue degradative enzymes such as 
heparanase and elastases that are involved in the breakdown of basement membrane integrity during inflammation [139-140].

One of the major and potentially promising activities of sulfated fucans is their potent inhibitory effect on human complement activation. It is shown that fucoidan from $A$. nodosum potently inhibit both the classical and alternative pathways in human serum [141]. It is earlier reported that fucoidan with low molecular weight fractions bind to the $\mathrm{C} 1 \mathrm{q}$ subunit of the $\mathrm{C} 1$ complex that triggers complement through recognition and binding of immune complexes [142]. The binding of fucoidan appears to prevent the ability of C1q to fully trigger $\mathrm{C} 1$ activation [142]. It appears that fucoidan also binds with $\mathrm{C} 4$, thereby preventing its breakdown and generation of its cleavage product $\mathrm{C} 4 \mathrm{~b}$, the latter being required for the formation of $\mathrm{C} 3$ convertase and the propagation of complement. Furthermore, it was found that fucoidan binds C1q globular heads and may interfere with C1q recognition of IgG [143]. Recently, by NMR, it was found that branched fucoidan oligosaccharides are better at inhibiting complement than linear structures [144].

The interaction of algal sulfated polysaccharides with the complement system indicate that they the ability to influence innate immunity in order to reduce the proinflammatory state or other serious conditions such as allergic reactions arising during the innate immune response. Moreover, there is growing potential evidence that algal polysaccharides can regulate the innate immune response directly by binding to pattern recognition receptors (PRRs) such as the mannose receptor and toll-like receptors on phagocytic cells including macrophages [134]. For instance, $\lambda$-carrageenan generated a $\mathrm{T}$ helper $1(\mathrm{Th} 1)$ patterned cytokine response in mouse T cell cultures via toll like receptor-4 (TLR4) [145]. However, splenocytes prepared from TLR4 deficient mice, when treated with $\lambda$-carrageenan, were able to produce interferon- $\gamma$, indicating that other than TLR4, pattern recognition receptors were also elicited. Furthermore oral dosing with $\lambda$-carrageenan in mice immunized with ovalbumin to produce an allergic reaction, showed reduced ovalbumin-specific IgE and delayed serum histamine release. This clearly shows that probably $\lambda$-carrageenan reduced the allergic reactions. Similar results were reported for fucoidan from $U$. pinnatifida [146].

Fucoidan also stimulates the immune system in various ways by modifying cell surface properties [147]. It was reported that, oral consumption of fucoidans from brown seaweeds, inhibited viral replication and stimulate the immune system functions [148]. In immunosuppressed mice the immune functions has been found to be restored by fucoidan. It acts as an immunomodulator directly on macrophage, T lymphocyte, B cell, natural killer cells (NK cell) [149]. In irradiated rats they promote the recovery of immunologic function [150], induce the production of interleukin (IL-1) and interferon- $\gamma$ (IFN- $\gamma$ ) in vitro. They also found to promote the primary antibody response in sheep red blood cells in vivo [151].

Algal polysaccharides-directed stimulatory effects on immune cells results in production of nitric oxide through inducible nitric oxide synthase (iNOS) and a proinflammatory cytokine/chemokine profile [152]. For example,in RAW264.7 macrophage cells, $F$. vesiculosus fucoidan induced iNOS leading to enhanced production of nitric oxide [153-154]. However, in the presence of lipopolysaccharide (LPS), the fucoidan impaired LPS-induced expression of iNOS and nitric oxide production [154]. Similarly, fucoidan suppresses interferon- $\gamma$-induced iNOS expression in glial cells and macrophage [155]. These and other reports of algal sulfated polysaccharides directly stimulating the innate immune system [152, 155-156] suggests that they may find therapeutic use in opposing $\mathrm{T}$ helper2 (Th2)-based pathologies such as autoimmune disorders and allergy. Leiro and co-workers [152] reported that when ulvan-like polysaccharides from $U$. rigida were desulfated, 
theygreatly diminished immunostimulatory activity.The structural requirements for this immunostimulatory activity of algal sulfated polysaccharides are yet to be studied in depth.

Dietery fibres: Seaweed contains significantly higher amount of total fibre content ranging from 33-50\% in terms of dry weight basis, when compared to higher plants. These fibres are rich in soluble fractions [157]. In marine algae the dietary fibres are classified into two types, i.e. insoluble fibres such as mannans, xylan and cellulose; and water soluble dietary fibres such as laminarin, agars, furonan, porphyran, and alginic acid. The total dry weight content of dietary fibres n Undaria, Fucus, Porphyra and Saccharina are $58 \%, 50 \%, 30 \%$ and $29 \%$ respectively [6]. Moreover, Fucus and Laminaria have $40 \%$ and $27 \%$ of insoluble dietary fibre content and Undaria pinnatifida (wakame), Chondrus and Porphyra have 15-22\% of soluble dietary fibres content [158]. The seaweed undigested polysaccharides can form important sources of dietary fibres, although they might change digestibility of dietary protein and minerals. The seaweed dietary fibres contain some important substances and nutrients, which has been a deal of interest in seaweed meal, functional foods, and nutraceuticals for human consumption [159]. Moreover, polysaccharides also show antihepatitic and antitumor bioactivity, significant anticoagulant activity, decrease LDL cholesterols in rats (hypercholesterolemia), they prevent large intestine cancer diabetes, obesity and showed antiviral activities [6, 15, 86, 160-162]. It is also observed that after the addition of soluble fibres, the glucose availability and absorption are delayed in the proximal small intestine thus reducing postprandial glucose levels [163-164]. It was also reported that water insoluble polysaccharides (celluloses) are mainly associated with a decrease in digestive tract transit time.

\section{Biotechnological applications of sulfated polysaccharides}

The growth of seaweed production and developments of advanced technological farming indicates that the seaweed industry is progressively evolving and thus paves the way to new application opportunities [165]. For many years, seaweed have been utilized as a source of dietary nourishment among Asian constituents. In recent years, more applications have used seaweed resources because of their unique characteristics and properties. Seaweed has been proposed as a source of important compound that can be incorporated in the production of functional food ingredients, pharmaceuticals, and cosmetics [166-168]. Gel-forming polysaccharides such as carrageenan and alginate are mostly known and commercially important seaweed products. Production of alternative fuels from non-starch biomass has recently directed the attention to utilization of marine macroalgae as sources of biomass for biofuel production [169]. Some of the applications of seaweed products are discussed below. Alginates:As described earlier, alginate is a gel-forming sulfated polysaccharide extracted from brown seaweed and has been utilized for various applications including foods and feeds, pharma/medical, and industrial preparations. Earlier reports on alginic acid-induced decrease in the cholesterol concentration have shown to play an important role as dietary fibre for the maintenance of animal and human health. These can exert an antihypertensive effect and can also block absorption of toxic chemical substances [6, 59]. It was also found to clear the digestive system, protect against carcinogens and shield surface membranes of the intestine and stomach. It can eliminate cholesterol from the digestive system by absorbing them, thereby resulting in hypocholesterolemic and hypolipidemic responses [170-174]. This is often associated with an increase in the faecal cholesterol content and a hypoglycaemic response [175-177]. Alginates, fucoidans, and laminarin extracts were tested against various bacteria, including Escherichia coli, Staphylococcus and Salmonella, Listeria etc. All the 
polysaccharides were found to show antibacterial effect efficiently against $E$. coli and Staphylococcus. Sodium alginate showed effective antibacterial effect.It not only binds to the bacteria strongly but also kills it. Kimura et al. [178] (1996) showed that alginates with molecular weights $\leq 50 \mathrm{kDa}$ prevented hypocholesterolemia, diabetes and obesity [178]. Research on volunteers who were $25-30 \%$ overweight showed decreased body weight when given a drug containing alginic acid [179]. Similarly, when $5 \mathrm{~g}$ of sodium alginate given every morning to patients having type II diabetes, it was found to prevent a postprandial increase of insulin, glucose, C-peptide levels and reduced gastric transit [180]. Moreover, meals supplemented with $5 \%$ kelp alginates decreased glucose absorption balance over 8 hours in pigs [181]. Another important health benefit of alginates is its property of gelation or precipitation with divalent metallic ions. No intestinal enzymes can digest alginic acid. So when heavy metals are accidentally taken into the human body, they can be made insoluble in the intestines by taking alginic acid and hence cannot be absorbed into the body tissue [48]. Alginic acid has been used to cure duodenal ulcers and gastritis for long and moreover alginates as an anti-ulcer agent has been used in various countries such as the USA, Germany, Canada, Japan and Belgium, [182-184]. In humans several products of alginate containing drugs such as Algitec- made of sodium alginate and cimetidine, Gaviscon- made of sodium alginate, sodium bicarbonate, and calcium carbonate and Gastralgin- made of alginic acid, sodium alginate, aluminium hydroxide, magnesium hydroxide and calcium carbonate have been shown to effectively suppress postprandial and acidic refluxes, binding of bile acids and prevent duodenal ulcers [185-187].

Alginates have another advantage that is exploited in surgery - an absorbing hemostatic effect. A variety of swabs, gauze dressings, cotton and materials saturated with a solution of sodium alginate have been developed and used for external use. They find application onto bleeding points during abdominal operations on parenchymatous organs $[185,187]$. Alginates can have a wide range of effects on platelet activation and prothrombotic blood coagulation. However, the degree of these effects is tied to the ratio between the guluronic and mannuronic chains in the molecule, along with the calcium concentration. Alginates with a zinc ion were shown to have the most significant hemostatic effects [188]. Katayama et al. [189] suggested that Poraprezinc-sodium alginate (a high performance mixture) suspension can be used for the treatment of severe cold sores that have been complicated by hemorrhagic erosions and ulcer. Alginate fibres form a gel-like substance by swelling when applied to the tooth surface. That creates a matrix for coagulation. Alginate dressings are also used to pack tooth cavities, sinuses and fistulas [190]. In addition, "Detoxal", a bioactive food additive that contains calcium alginate was found to have anti-toxic effects on hepatitis [6]. Detoxal normalizes the glycogen and lipids concentration in the liver and decreases the lipid peroxidation products [185].

Agar:It has been reported that agar-agar decreases in the concentration of blood glucose and exerts an anti-aggregation effect on red blood cells. It has also been found to impact absorption of ultraviolet rays [6]. Antitumor activity was found in an agar-type polysaccharide in Gracilaria species. Moreover, antioxidant potential and activity against $\alpha$ glucosidase was showed by agaro-oligosaccharides [191-192]. Agarose can be separated from the agar with a yield of $42 \%$ and in Gelidium spp, the agar content varied seasonally from $26-42 \%$ [20, 193]. Furthermore, the agaro-oligosaccharides have also been showed the ability to suppress the pro-inflammatory responses. 


\section{Future Prospects and Conclusion}

Marine organisms in general, and algae in particular, are highly interesting sources for a variety of different bioactive polysaccharides. These range from new food applications to industrial applications. They also hold many exotic polysaccharides that are at this moment being explored for functional properties in biomedicine and food. The therapeutic benefits of algal sulfated polysaccharides are currently being explored. Their heterogeneity and structural diversity though, make it challenging to study them in detail. It is highly likely that these challenges have thus far held back their development as therapeutic agents. In addition, the pharmacological and structural features are also likely to vary based on species, time of harvest and location. This compounds the challenges in creating a standardized commercial product that is based on algal sulfated polysaccharide constituents. To summarize, there are already a wide variety of biomedical and biotechnological applications of algal sulfated polysaccharides, and there is significant ongoing interest in further understanding the structure-function relationship, so they can be used for producing more bioactive products.

Table.4. Various applications of algal sulfated polysaccharides from some reported seaweeds ([4])

\begin{tabular}{|c|c|c|c|}
\hline Seaweed & Sulfated Polysaccharide & Bioactivity & Reference \\
\hline $\begin{array}{l}\text { Gracilaria birdiae } \\
\text { (red) }\end{array}$ & Fucoidan & Antioxidant & Souza et al. (2012) \\
\hline $\begin{array}{l}\text { Gigartina skottsbergii } \\
\text { (red) }\end{array}$ & Carrageenan & Antioxidant & Barahona et al. (2011) \\
\hline $\begin{array}{c}\text { Schizymenia binderi } \\
\text { (red) }\end{array}$ & Rhamnan & Antioxidant & Magalhaes et al. (2011) \\
\hline $\begin{array}{l}\text { Lessonia vadosa } \\
\text { (brown) }\end{array}$ & Hetrofucan & Antioxidant & Costa et al. $(2011 a, b)$ \\
\hline $\begin{array}{c}\text { Sargassum filipendula } \\
\text { (brown) }\end{array}$ & Sulfate polysaccharide & Antioxidant & Devaki et al. (2009) \\
\hline $\begin{array}{c}\text { Laminaria japonica } \\
\text { (brown) }\end{array}$ & Heterofucan & Antioxidant & Camara et al. (2011) \\
\hline Ulva lactuca (green) & Sulfated polysaccharides & Antioxidant & Hu et al. (2010) \\
\hline $\begin{array}{c}\text { Canistrocarpus } \\
\text { cervicornis (brown) }\end{array}$ & Sulfated polysaccharide & Antioxidant & Yang et al. (2011) \\
\hline $\begin{array}{l}\text { Undaria pinnitafida } \\
\text { (brown) }\end{array}$ & Sulfated polysaccharide & Antioxidant & Costa et al. (2010) \\
\hline $\begin{array}{l}\text { Lessonia vadosa } \\
\text { (brown) }\end{array}$ & Heterofucan & Antioxidant & Costa et al. (2011a, b) \\
\hline $\begin{array}{c}\text { Saccharina japonica } \\
\text { (brown) }\end{array}$ & Sulfated polysaccharide & Antitumor & Vishchuk et al. (2011) \\
\hline $\begin{array}{l}\text { Undaria pinnatifida } \\
\text { (brown) }\end{array}$ & Sulfated polysaccharide & Antitumor & Costa et al. (2010) \\
\hline $\begin{array}{c}\text { Caulerpa prolifera } \\
\text { (green) }\end{array}$ & Fucan & Antitumor & Croci et al. (2011) \\
\hline $\begin{array}{c}\text { Dictyota menstrualis } \\
\text { (brown) }\end{array}$ & Fucoidan & Antitumor & Ermakova et al. (2011) \\
\hline $\begin{array}{c}\text { Monostroma nitidum } \\
\text { (green) }\end{array}$ & Heterofucan & Antitumor & Costa et al. $(2011 a, b)$ \\
\hline $\begin{array}{c}\text { Sargassum pallidum } \\
\text { (brown) }\end{array}$ & Heterofucan & Antitumor & Magalhaes et al. (2011) \\
\hline Laminaria saccharina & Fucoidan & Antitumor & Jin et al. (2010) \\
\hline
\end{tabular}


DOI : $\underline{\text { https://dx.doi.org/10.26808/rs.ph.i7v5.02 }}$

International Journal of Pharmaceutical Science and Health

Available online on http://www.rspublication.com/ijphc/index.html

Issue 7, Vol. 5 (September- October 2017)

\begin{tabular}{|c|c|c|c|}
\hline \multicolumn{4}{|c|}{ Available online on http://www.rspublication.com/ijphc/index.html $\quad$ ISSN 2249-5738 } \\
\hline (brown) & & & \\
\hline $\begin{array}{l}\text { Ecklonia cava } \\
\text { (brown) }\end{array}$ & Sulfated polysaccharide & Antitumor & Lins et al. (2009) \\
\hline $\begin{array}{c}\text { Sargassum hornery } \\
\text { (brown) }\end{array}$ & Fucoidan & Antitumor & Foley et al. (2011) \\
\hline $\begin{array}{c}\text { Enteromorpha } \\
\text { prolifera (green) }\end{array}$ & Fucoidan & Immunostimulatory & Kim et al. $(2011,2012)$ \\
\hline $\begin{array}{c}\text { Champia feldmannii } \\
\text { (red) }\end{array}$ & j-carrageenan & Immunostimulatory & Lins et al. (2009) \\
\hline $\begin{array}{l}\text { Fucus vesiculosus } \\
\text { (brown) }\end{array}$ & Oligosaccharides & Immunostimulatory & Kawashima et al. (2011) \\
\hline $\begin{array}{l}\text { Solieria filiformis } \\
\text { (red) }\end{array}$ & Galactan & Antiinflammation and & de Arau'jo et al. (2011) \\
\hline Gelidium crinale (red) & Mannoglucuronofucans & antinociceptive & Farias et al. (2011) \\
\hline $\begin{array}{c}\text { Sargassum } \\
\text { hemiphyllum (brown) }\end{array}$ & $\mathrm{j}$-carrageenan & $\begin{array}{l}\text { Antiinflammation and } \\
\text { antinociceptive }\end{array}$ & de Sousa et al. (2011a) \\
\hline $\begin{array}{l}\text { Gracilaria cornea } \\
\text { (red) }\end{array}$ & Oligosaccharides & $\begin{array}{l}\text { Antiinflammation and } \\
\text { antinociceptive }\end{array}$ & Hwang et al. (2011) \\
\hline $\begin{array}{c}\text { Padina gymnospora } \\
\text { (brown) }\end{array}$ & Fucan & $\begin{array}{l}\text { Antiinflammation and } \\
\text { antinociceptive }\end{array}$ & Marques et al. (2012) \\
\hline $\begin{array}{l}\text { Ecklonia cava } \\
\text { (brown) }\end{array}$ & Arabinogalactans & $\begin{array}{l}\text { Anticoagulation and } \\
\text { antithrombosis }\end{array}$ & Wijesinghe et al. (2011) \\
\hline $\begin{array}{c}\text { Dictyota cervicornis } \\
\text { (brown) }\end{array}$ & Rhamnan & $\begin{array}{c}\text { Anticoagulation and } \\
\text { antithrombosis }\end{array}$ & Costa et al. (2010) \\
\hline $\begin{array}{l}\begin{array}{c}\text { Codium fragile } \\
\text { (green) }\end{array} \\
\end{array}$ & Sulfated polysaccharide & $\begin{array}{c}\text { Anticoagulation and } \\
\text { antithrombosis }\end{array}$ & Li et al. (2011) \\
\hline $\begin{array}{c}\text { Monostroma } \\
\text { latissimum (green) }\end{array}$ & Heterofucan & $\begin{array}{l}\text { Anticoagulation and } \\
\text { antithrombosis }\end{array}$ & Camara et al. (2011) \\
\hline $\begin{array}{c}\text { Dictyota menstrualis } \\
\text { (brown) }\end{array}$ & Fucan & $\begin{array}{l}\text { Anticoagulation and } \\
\text { antithrombosis }\end{array}$ & Croci et al. (2011) \\
\hline $\begin{array}{c}\text { Gyrodinium } \\
\text { impudium (red) }\end{array}$ & Galactan & $\begin{array}{c}\text { Antiviral (Influenza, } \\
\text { herpes, HIV) }\end{array}$ & Ghosh et al. (2009) \\
\hline $\begin{array}{c}\text { Nemalion } \\
\text { helminthoides }(\mathrm{red})\end{array}$ & Mannans & $\begin{array}{c}\text { Antiviral (Influenza, } \\
\text { herpes, HIV) }\end{array}$ & Kim et al. $(2011,2012)$ \\
\hline $\begin{array}{l}\text { Boergeseniella } \\
\text { thuyoides (red) }\end{array}$ & Xylogalactofucan & $\begin{array}{c}\text { Antiviral (Influenza, } \\
\text { herpes, HIV) }\end{array}$ & Bouhlal et al. (2011) \\
\hline $\begin{array}{c}\text { Sebdenia polydactyla } \\
\text { (red) }\end{array}$ & Xylomannan & $\begin{array}{c}\text { Antiviral (Influenza, } \\
\text { herpes, HIV) }\end{array}$ & $\begin{array}{c}\text { Bandyopadhyay et al. } \\
\text { (2011) }\end{array}$ \\
\hline Ulva lactuca (green) & Fucoidan & Lipid lowering & Kim et al. (2010) \\
\hline $\begin{array}{c}\text { Sargassum } \\
\text { polycystum (brown) }\end{array}$ & Sulfated polysaccharide & Lipid lowering & Sathivel et al. (2008) \\
\hline Brown seaweeds & Fucoidan & $\begin{array}{c}\text { Regenerative and nano } \\
\text { medicine }\end{array}$ & Sezer et al. (2008) \\
\hline Ulva rigida (green) & Ulvan & $\begin{array}{l}\text { Regenerative and nano } \\
\text { medicine }\end{array}$ & Murakami et al. (2010) \\
\hline
\end{tabular}

\section{Acknowledgments}

This review has been supported by Department of Atomic Energy, India. 


\section{References}

[1] S.K. Kim, and I. Wijesekara, Development and biological activities of marine derived bioactive peptides: a review, Journal of Functional Foods., Vol. 2, pp. 1-9, 2010.

[2] S.A. Pomponi, The bioprocess technological potential of the sea, Journal of Biotechnology., Vol. 70, pp. 5-13, 1999.

[3] C. Barrow, and F. Shahidi, Marine nutraceuticals and functional foods, New York, USA: CRC Press, Taylor and Francis group, New York, pp. 23-6, 2008.

[4] P. Seema, Therapeutic importance of sulfated polysaccharides from seaweeds: updating the recent findings, 3 Biotech., Vol. 2, pp. 171-185, 2012.

[5] C.S. Kumar, P. Ganesan, and N. Bhaskar, In vitro antioxidant activities of three selected brown seaweeds of India, Food Chemistry., Vol. 107, pp.707-713, 2008a.

[6] M. Murata, and J. Nakazoe, Production and use of marine algae in Japan. Jarq-Japan Agricultural Research Quarterly., Vol. 35, pp.281-290, 2001.

[7] D.J. McHugh, Production and utilization of products from commercial seaweeds. FAO Fisheries Technical Paper., Vol. 288, pp.1-189, 1987.

[8] C.K. Tseng, Algal biotechnology industries and research activities in China, Journal of Applied Phycology, Vol.13, pp. 375-380, 2001.

[9] H.J. Bixler, H. Porse, A decade of change in the seaweed hydrocolloids industry, Journal of Applied Phycology., Vol. 23, pp. 321-335, 2010.

[10] S. Kraan, Algal Polysaccharides, Novel Applications and Outlook. Chap. 22 in Carbohydrates-comprehensive 607 studies on glycobiology and glycotechnology., 2012.

[11] S. Holdt, and S. Kraan, Bioactive compounds in seaweed; functional food applications and legislation, Journal of Applied Phycology., Vol. 23, pp. 543-597, 2011.

[12] N.M. Mestechkina, and V.D. Shcherbukhin, Sulfated polysaccharides and their anticoagulant activity: A Review, Applied Biochemistry and Microbiology., Vol. 46, pp.267273,2010.

[13] P.A. Hwang, S.Y. Chien, Y.L. Chan, M.K. Lu, C.H. Wu, Z.L. Kong, C.J. Wu, Inhibition of lipopolysaccharide (LPS)-induced inflammatory responses by Sargassum hemiphyllum sulfated polysaccharide extract in RAW 264.7 Macrophage Cells, Journal of Agricultural Food Chemistry., Vol. 59, pp. 2062-2068, 2011.

[14] J. Guangling, Y. Guangli, Z. Junzeng, and H.E. Stephen, Chemical structures and bioactivities of sulfated polysaccharides from marine algae, Marine Drugs., Vol. 9, pp.196223, 2011.

[15] J.B. Lee, K. Hayashi, M. Hashimoto, T. Nakano, and T. Hayashi, Novel antiviral fucoidan from sporophyll of Undaria pinnatifida (Mekabu). Chemical Pharmaceutical Bulletin.,Vol.52,pp.1091-1094,2004.

[16] V.L.Sirisha, D.S. Jacinta, Algal polysaccharides and their biological applications. In: marine algae extracts: Processes, products and applications. Ed Se-Kwom Kim and Katarzyna Chojnacka. DOI: 10.1002/9783527679577.ch26,2015

[17] H.P. Vitor, Structural and functional insights into sulphated galactans: a systematic review. Glycoconjugate Journal., Vol.27, pp.1-12, 2010.

[18] R.S. Rasmussen, and M.T. Morrissey, Marine biotechnology for production of food ingredients. In: Taylor, S.L., Ed., Advances in Food and Nutrition Research., Vol. 52, Elsevier, New York, pp. 237-292, 2007.

[19] FAO, Effects of food processing on dietary carbohydrates. Asia Pacific Food industry., Vol. 20, pp. 64-69, 2008. 
[20] Y.J. Jeon, Y. Athukorala, and J. Lee, Characterization of agarose product from agar using DMSO, Algae., Vol. 20, pp. 61-67, 2005.

[21] E.L.Mccandles, and J.S. Craigie, Sulphated polysaccharides in red and brown algae, Planta., Vol. 112, pp. 201-212, 1979.

[22] R. Falshaw, H.J. Bixler, and K. Johndro, Structure and performance of commercial kappa-2 carrageenan extracts: I. Structure analysis. Food Hydrocolloids., Vol.15, pp. 441-52, 2001.

[23] M.T. Nickerson, R. Darvesh, and A.T. Paulson, Formation of calcium-mediated junction zones at the onset of the sol-gel transition of commercial k-carrageenan solutions, Journal of Food Science., Vol. 75, pp. 153-6, 2010.

[24] M. Glicksman, Utilization of seaweed hydrocolloids in the food industry. Hydrobiologia., Vol.151-152, pp. 31- 47, 1987.

[25] S.E. Harding, K. Day, R. Dhami, and P.M. Lowe, Further observations on the size, shape and hydration of kappa carrageenan in dilute solution, Carbohydrate Polymers., Vol. 32, pp. 81-7, 1997.

[26] [27] F. van de Velde, A.S. Antipova, H.S. Rollema, T.V. Burova, N.V. Grinberg, L. Pereira, P.M. Gilsenan, R.H. Tromp, B. Rudolph, and V.Y. Grinberg, The structure of kappa/iota-hybrid carrageenans II. Coil-helix transition as a function of chain composition, Carbohydrate Research., Vol. 340, pp. 1113-1129, 2005.

[27] F. van de Velde, S.H. Knutsen, A.I. Usov, H.S. Rollema, and A.S. Cerezo, 1H and 13C high resolution NMR spectroscopy of carrageenans: application in research and industry, Trends in Food Science and Technology., Vol.13, pp.73- 92, 2002.

[28] K.A. Pittman, L. Goldberg, and F. Coulston, Carrageenan: the effect of molecular weight and polymer type on its uptake, excretion and degradation in animals. Food and Cosmetics Toxicology., Vol.14, pp. 85-93, 1976.

[29] G. Opoku, X. Qiu, and V. Doctor, Effect of over sulfation on the chemical and biological properties of kappa carrageenan, Carbohydrate Polymer., Vol. 65, pp. 134-8, 2006.

[30] J.R. Waaland, and C.A. Lembi, Algae and human affairs. New York: Cambridge University Press, Berkley, pp 726-741, 1988.

[31] K.O. Ribeiro, M.I. Rodrigues, E. Sabadini, and R.L. Cunha, Mechanical properties of acid sodium caseinate-i carrageenan gels: effect of co-solute addition. Food Hydrocolloids., Vol.18, pp. 719, 2004.

[32] K.C. Guven, K. Akyuz, T. Yurdun, Selectivity of heavy metal binding by algal polysaccharides. Toxicology and Environmental Chemistry., Vol.47, pp.65-70, 1995.

[33] P.Ch. Brenden, and K.T. Bird, Effects of environmental factors on carrageenan from Gymnogongrus griffithsiae (Gigartinales, Rhodophyta). Journal of Applied Phycology., Vol. 6, pp. 371-380, 1994.

[34] K. Gekko, H. Mugishima, and S. Koga, Effects of sugars and polyols on the sol-gel transition of k-carrageenan: calorimetric study. International Journal of Biological Macromolecules., Vol. 9, pp. 146- 52, 1987.

[35] H.J. Bixler, The Carrageenan Connection IV. British Food Journal., Vol. 96, pp. 2-7, 1994.

[36] V. Langendorff, G. Cuvelier, C. Michon, B. Launay, A. Parker, and C.G. De Kruif, Effects of carrageenan type on the behaviour of carrageenan/milk mixtures, Food Hydrocolloids., Vol. 14, pp. 273-80, 2000. 
[37] Y.S. Gu, E.A. Decker, and D.J. McClements, Influence of $\mathrm{pH}$ and carrageenan type on properties of $\beta$-lactoglobulin stabilized oil-in-water emulsions, Food Hydrocolloids., Vol. 19, pp. 83-91, 2005.

[38] A. Grenha, M.E. Gomes, M. Rodrigues, V.E. Santo, J.F. Mano, N.M. Neves et al, Development of new chitosan/ carrageenan nanoparticles for drug delivery applications. Journal of Biomedical Material Research A., Vol. 92, pp. 1265-72, 2010.

[39] L.A.A. Ahmad Bani-Jaber, H. Alkhatib, B. Al-Khalidi, Prolonged Intragastric Drug Delivery Mediated by Eudragit E-Carrageenan Polyelectrolyte Matrix Tablets, AAPS PharmSciTech., Vol. 12, pp. 354-61, 2011.

[40] M. Lahaye, and A. Robic, Structure and functional properties of ulvan, a polysaccharide from green seaweeds, Biomacromolecules., Vol. 8, pp. 1765-1774, 2007.

[41] M. Lahaye, NMR spectroscopic characterisation of oligosaccharides from two Ulva rigida ulvan samples (Ulvales, Chlorophyta) degraded by a lyase, Carbohydrate Research., Vol. 314, pp. 1-12, 1998.

[42] X. Briand, S. Cluzet, B. Dumas, M.T. Esquerré-Tugayé, and S. Salamagne, Ulvans as activators of plant defense and resistance reactions against biotic and abiotic stresses. US Patent 7,820,176, 26 October, 2010.

[43] X. Briand, S. Cluzet, B. Dumas , M.T. Esquerré-Tugayé, S. Salamagne, Use of Ulvans as elicitors of mechanisms for nitrogen absorption and protein synthesis. US Patent 7,892,311, 22 February, 2011.

[44] V. Jaulneau, C. Lafitte, C. Jacquet, S. Fournier, S. Salamagne, X. Briand, M.T. Esquerré-Tugayé, and B. Dumas, Ulvan, a sulphated polysaccharide from green algae, activates plant immunity through the jasmonic acid signaling pathway, Journal of Biomedical Biotechnology., Vol. 525291, pp. 11, 2010.

[9] Harris J. Bixler, Hans Porse, A decade of change in the seaweed hydrocolloids industry, Journal of Applied Phycology., Vol. 23(3), pp. 321-335, 2011.

[45] S. Arasaki, and T. Arasaki, Low calorie, high nutrition vegetables from the sea. To help you look and feel better. Japan Publications, Tokyo, pp.6-196, 1983.

[46] G. Jiao, G. Yu, J. Zhang, and H.S. Ewart, Chemical structures and bioactivities of sulfated polysaccharides from marine algae, Marine Drugs., Vol. 9, pp.196-223, 2011.

[47] B. Yang, G. Yu, X. Zhao, W. Ren, G. Jiao, L. Fang, Y. Wang, G. Du, C. Tiller, G. Girouard, C.J. Barrow, H.S. Ewart, and J. Zhang, Structural characterisation and bioactivities of hybrid carrageenan-like sulphated galactan from red alga Furcellaria lumbricalis, Food Chemistry., Vol. 124, pp. 50-57, 2011.

[48] A.D. Augst, H.J. Kong, and D.J. Mooney, Alginate Hydrogels as Biomaterials. Macromolecules Bioscience., Vol. 6, pp. 623-633, 2006.

[49] V.J. Chapman, Seaweeds and their uses. 2nd edn. Methuen, London, pp.304, 1970.

[50] J. Vera, J. Castro, A. Gonzalez, and A. Moenne, Seaweed polysaccharides and derived oligosaccharides stimulate defence responses and protection against pathogens in plants, Marine Drugs., Vol. 9, pp. 2514-25, 2011.

[51] Berteau O Mulloy B, Sulfated fucans, fresh perspectives: structures, functions, and biological properties of sulfated fucans and an overview of enzymes active toward this class of polysaccharide, Glycobiology., Vol. 13, pp. 29-40, 2003.

[52] L. Chevolot, B. Mulloy, J. Ratiskol, A. Foucault, and S. Colliec-Jouault, A disaccharide repeat unit is the major structure in fucoidans from two species of brown algae, Carbohydrate Research., Vol. 330, pp. 529-535, 2001. 
[53] N.P. Chandía, and B. Matsuhiro, Characterization of a fucoidan from Lessonia vadosa (Phaeophyta) and its anticoagulant and elicitor properties, International Journal of Biological Macromolecules., Vol. 42, pp. 235-240, 2008.

[54] A. Holtkamp, Isolation, Characterisation, modification and application of fucoidan from Fucus vesiculosus, Braunschweig: Technischen Universit Carolo Wilhelmina, 2009.

[55] L.E. Rioux, S.L. Turgeon, and M. Beaulieu, Characterization of polysaccharides extracted from brown seaweeds, Carbohydrate Polymers., Vol. 69, pp. 530-7, 2007.

[56] W.A.J.P. Wijesinghe, and Y.J. Jeon, Biological activities and potential industrial applications of fucose rich sulfated, polysaccharides and fucoidans isolated from brown seaweeds: A review, Carbohydrate Polymers., Vol .88, pp. 13-20, 2012.

[57] T.Y. Nagai, Preparation and functional properties of beverages made from sea algae, Food Chemistry., Vol. 81, pp. 327-32, 2003.

[58] I. López-López, S. Bastida, C. Ruiz-Capillas, L. Bravo, M.T. Larrea, F. Sánchez-Muniz, S. Cofrades, and F. Jiménez-Colmenero, Composition and antioxidant capacity of low-salt meat emulsion model systems containing edible seaweeds, Meat Science., Vol. 83, pp. 492-8, 2009.

[59] M.H. Kim, and H.G. Joo, Immunostimulatory effects of fucoidan on bone marrowderived dendritic cells, Immunology Letters., Vol. 115, pp. 138-143, 2008.

[60] A.O. Chizhov, A. Dell, H.R. Morris, A.J. Reason, S.M. Haslam, R.A. McDowell, O.S. Chizhov, and A.I. Usov, Structural analysis of laminarans by MALDI and FAB mass spectrometry, Carbohydrate Research., Vol. 310, pp. 203-210, 1998.

[61] C. Deville, J. Damas, P. Forget, G. Dandrifosse, and O. Peulen, Laminarin in the dietery fibre concept, Journal of Science Food and Agriculture., Vol. 84, pp. 1030-1038, 2004.

[62] H.Q. Miao, M. Elkin, E. Aingorn, R. Ishai-Michaeli, C.A. Stein, and I. Vlodavsky, Inhibition of heparanase activity and tumor metastasis by laminarin sulfate and synthetic phosphorothioate oligodeoxynucleotides, International Journal of Cancer., Vol. 83, pp. 42431, 1999.

[63] P. Macartain, C.I.R. Gill, M. Brooks, R. Campbell, and I.R. Rowland, Nutritional value of edible seaweeds. Nutrition Reviews., Vol. 65, pp. 535-543, 2007

[64] A. Jimenez-Escrig, and F.J. Sanchez-Muniz, Dietary fibre from edible seaweeds: chemical structure, physicochemical properties and effects on cholesterol metabolism, Nutrition Reviews., Vol. 20, pp. 585-598, 2000.

[65] H. Qi, Q. Zhang, T. Zhao, R. Hu, K. Zhang, and Z. Li, In vitro antioxidant activity of acetylated and benzoylated derivatives of polysaccharide extracted from Ulva pertusa (Chlorophyta), Bioorganic Medicine and Chemistry Letters., Vol. 16, pp. 2441-2445, 2006.

[66] P. Ruparez, O. Ahrazem, and J.A. Leal, Potential antioxidant capacity of sulfated polysaccharides from the edible marine brown seaweed Fucus vesiculosus, Journal of Agricultural Food Chemistry., Vol. 50, pp. 840-845, 2002.

[67] M. Rocha de Souza, C. Marques, C. Guerra Dore, F. Ferreira da Silva, H. Oliveira Rocha, and E. Leite, Antioxidant activities of sulfated polysaccharides from brown and red seaweeds, Journal of Applied Phycology., Vol. 19, pp. 153-160, 2007.

[68] X. Zhao, C. Xue, Y. Cai, D. Wang, and Y. Fang, Study of antioxidant activities of fucoidan from Laminaria japonica, High Technology Letters., Vol. 11, pp. 91-94, 2005.

[69] L.S. Costa, G.P. Fidelis, S.L. Cordeiro, R.M. Oliveira, D.A. Sabry, R.B.G. Ciara, H.A.O. Nobre, L.T.D.B. Costa, M.S.S.P. Almeida-Lima, J. Farias, E.H.C. Leite, and E.L. Rocha, Biological activities of sulfated polysaccharides from tropical seaweeds, Biomedical. Pharmacotherapy., Vol. 64, pp. 21-28, 2010. 
[70] J. Wang, Q. Zhang, Z. Zhang, H. Song, and P. Li, Potential antioxidant and anticoagulant capacity of low molecular weight fucoidan fractions extracted from Laminaria japonica, International Journal of Biological Macromolecules., Vol. 46, pp. 6-12, 2010.

[71] J. Wang, L. Liu, Q. Zhang, Z. Zhang, H. Qi, and P. Li, Synthesized oversulfated, acetylated and benzoylated derivatives of fucoidan extracted from Laminaria japonica and their potential antioxidant activity in vitro, Food Chemistry., Vol. 114, pp. 1285-1290, 2009. [72] Q.B. Zhang, N. Li, G.F. Zhou, X.L. Lu, Z.H. Xu, and Z. Li, In vivo antioxidant activity of polysaccharide fraction from Porphyra haitanesis (Rhodephyta) in aging mice, Pharmacological Research., Vol. 48, pp. 151-155, 2003.

[73] H.M. Qi, Q.B. Zhang, T.T. Zhao, R. Chen, H. Zhang, X.Z. Niu, and Z. Li, Antioxidant activity of different sulfate content derivatives of polysaccharide extracted from Ulva pertusa (Chlorophyta) in vitro, International Journal of Biological Macromolecules., Vol. 37, pp. 195-199, 2005a.

[74] H.M. Qi, T.T. Zhao, Q.B. Zhang, Z. Li, Z.Q. Zhao, and R. Xing, Antioxidant activity of different molecular weight sulfated polysaccharides from Ulva pertusa Kjellm (Chlorophyta). Journal of Applied Phycology., Vol. 17, pp. 527-534, $2005 \mathrm{~b}$.

[75] C.H. Xue, L. Chen, Z.J. Li, Y.P. Cai, H. Lin, and Y. Fang, Antioxidative activities of low molecular fucoidans from kelp Laminaria japonica, Developmental Food Science., Vol. 42, pp. 139-145, 2004.

[76] J.F. Hu, M.Y. Geng , J.T. Zhang, and H.D. Jiang, An in vitro study of the structureactivity relationships of sulfated polysaccharide from brown algae to its antioxidant effect, Journal of Asian Natural Products Research., Vol. 3, pp. 353-358, 2001.

[77] J. Wang, Q.B. Zhang, Z.S. Zhang, and Z. Li, Antioxidant activity of sulfated polysaccharide fractions extracted from Laminaria japonica, International Journal of Biological Macromolecules., Vol. 42, pp. 127-132, 2008.

[78] J. Wang, L. Liu, Q. Zhang, Z. Zhang, H. Qi, and P. Li, Synthesized oversulphated, acetylated and benzoylated derivatives of fucoidan extracted from Laminaria japonica and their potential antioxidant activity in vitro. Food Chemistry., Vol. 114, pp. 1285e1290, 2009. [79] H. Qi, Q. Zhang, T. Zhao, R. Chen, H. Zhang, X. Niu, and Z. Li, Antioxidant activity of different sulfate content derivatives of polysaccharide extracted from Ulva pertusa (Chlorophyta) in vitro, International Journal of Biological Macromolecules., Vol. 37, pp. 195-199, 2005.

[80] M.J. Vaquez-Freire, M. Lamela, and J.M. Calleja, Hypolipidaemic activity of a polysaccharide extract from Fucus vesiculosus, Phytotherapy Research., Vol. 10, pp. 647650, 1996.

[81] L. Huang, K. Wen, X. Gao, and Y. Liu, Hypolipidemic effect of fucoidan from Laminaria japonica in hyperlipidemic rats, Pharmaceutical Biology., Vol. 48, pp. 422-426, 2010.

[82] Y. Pengzhan, L. Ning, L. Xiguang, Z. Gefei, Z. Quanbin, and L. Pengcheng, Antihyperlipidemic effects of different molecular weight sulfated polysaccharides from Ulva pertusa (Chlorophyta), Pharmacological Research, Vol. 48, pp. 543-549, 2003.

[83] H.R. Raghavendran, A. Sathivel, and T. Devaki, Effect of Sargassum polycystum (Phaeophyceae)- sulfated polysaccharide extract against acetaminophen-induced hyperlipidemia during toxic hepatitis in experimental rats, Molecular and Cell Biochemistry., Vol. 276, pp. 89-96, 2005. 
[84] A. Josephine, C.K. Veena, G. Amudha, S.P. Preetha, and P. Varalakshmi, Protective role of sulphated polysaccharides in abating the hyperlipidemic nephropathy provoked by cyclosporine A, Archives of Toxicology., Vol. 81, pp. 371-379, 2007.

[85] M. Witvrouw, and E. DeClercq, Sulfated polysaccharides extracted from sea algae as potential antiviral drugs, General Pharmacology: The Vascular System, Vol. 29, pp. 497-511, 1997.

[86] D.J. Schaeffer, and V.S. Krylov, Anti-HIV activity of extracts and compounds from algae and cyanobacteria, Ecotoxicology and Environmental Safety, Vol. 45, pp. 208-227, 2000.

[87] E.B. Damonte, M.C. Matulewicz, and A.S. Cerezo, Sulfated seaweed polysaccharides as antiviral agents, Current Medicinal Chemistry., Vol. 11, pp. 2399-2419, 2004.

[88] M. Luescher-Mattli, Algae, a possible source for new drugs in the treatment of HIV and other viral diseases, Current Medicinal Chemistry, Vol. 2, pp. 219-225, 2003.

[89] P. Gerber, J.D. Dutcher, E.V. Adams, and J.H. Sherman, Protective effect of seaweed extracts for chicken embryos infected with influenza B or mumps virus, Proceedings of the Society for Experimental Biology and Medicine., Vol. 99, pp. 590-593, 1958.

[90] A.J. Nahmias, and S. Kibrick,. Inhibitory effect of heparin on herpes simplex virus, Journal of Bacteriology., Vol. 87, pp. 1060-1066, 1964.

[91] T. Ghosh, K. Chattopadhyay, M. Marschall, P. Karmakar, P. Mandal, and B. Ray, Focus on antiviral active sulfated polysaccharides: From structure-activity analysis to clinical evaluation, Glycobiology., Vol. 19, pp. 2-15, 2009.

[92] K.I.P.J. Hidari, N. Takahashi, M. Arihara, M. Nagaoka, K. Morita, and T. Suzuki, Structure and anti-dengue virus activity of sulfated polysaccharide from a marine alga, Biochemical and Biophysical Research Communication., Vol. 376, pp. 91-95, 2008.

[93] L.B. Talarico, and E.B. Damonte, Interference in dengue virus adsorption and uncoating by carrageenans, Virology, Vol. 363, pp. 473-485, 2007.

[94] L.B. Talarico, C.A. Pujol, R.G.M. Zibetti, P.C.S. Farea, M.D. Noseda, M.E.R. Duarte, and E.B. Damonte, The antiviral activity of sulfated polysaccharides against dengue virus is dependent on virus serotype and host cell, Antiviral Research., Vol. 66, pp. 103-110, 2005.

[95] P. Mandal, C.G. Mateu, K. Chattopadhyay, C.A. Pujol, E.B. Damonte, and B. Ray, Structural features and antiviral activity of sulphated fucans from the brown seaweed Cystoseira indica, Antiviral Chemistry and Chemotherapy., Vol. 18, pp. 153-162, 2007.

[96] M.S.A. Mohsen, S.F. Mohamed, F.M. Ali, and O.H. El-Sayed, Chemical Structure and Antiviral Activity of Water-soluble Sulfated Polysaccharides from Sargassum latifolium, Journal of Applied Science Research., Vol. 3, pp. 1178-1185, 2007.

[97] E.A. Harden, R. Falshaw, S.M. Carnachan, E.R. Kern, and M.N. Prichard, Virucidal activity of polysaccharide extracts from four algal species against herpes simplex virus, Antiviral Research., Vol. 83, pp. 282-289, 2009.

[98] M.J. Carlucci, L.A. Scolaro, M.D. Noseda, A.S. Cerezo, and E.B. Damonte, Protective effect of a natural carrageenan on genital herpes simplex virus infection in mice, Antiviral Research., Vol. 64, pp. 137-141, 2004.

[99] M. Shanmugam, and K.H. Mody, Heparinoid-active sulfated polysaccharides from marine algae as potential blood anticoagulant agents, Current Science, Vol. 79, pp. 16721683, 2000.

[100] P.J. Caceres, M.J. Carlucci, E.B. Damonte, B. Matsuhiro, and E.A. Zuniga, Carrageenans from chilean samples of Stenogramme interrupta (Phyllophoraceae): structural analysis and biological activity, Phytochemistry., Vol. 53, pp. 81-86, 2000. 
[101] M.J. Carlucci, C.A. Pujol, M. Ciancia, M.D. Noseda, M.C. Matulewicz, E.B. Damonte, A.S. Cerezo, Antiherpetic and anticoagulant properties of carrageenans from the red seaweed Gigartina skottsbergii and their cyclized derivatives: Correlation between structure and biological activity, International Journal of Biological Macromolecules, Vol. 20, pp. 97-105, 1997.

[102] G. Bernardi, and G.F. Springer, Properties of highly purified fucan, Journal of Biological Chemistry., Vol. 237, pp. 75-80, 1962.

[103] G.F. Springer, H.A. Wurzel, G.M. McNeal, N.J. Jr. Ansell, and M.F. Doughty, Isolation of anticoagulant fractions from crude fucoidan. Proceedings of the Society for Experimental Biology and Medicine, Vol. 94, pp. 404-409, 1957

[104] M. Kusaykin, I. Bakunina, V. Sova, S. Ermakova, T. Kuznetsova, N. Besednova, T. Zaporozhets, and T. Zvyagintseva, Structure, biological activity, and enzymatic transformation of fucoidans from the brown seaweeds, Biotechnology Journal., Vol. 3, pp. 904-915, 2008.

[105] B. Li, F. Lu, X. Wei, and R. Zhao, Fucoidan: structure and bioactivity, Molecules., Vol.13, pp.1671-1695, 2008.

[106] V.H. Pomin, and P.A.S. Mourao, Structure, biology, evolution, and medical importance of sulphated fucans and galactans, Glycobioliology., Vol. 18, pp. 1016-1027, 2008.

[107] N. Li, Q.B. Zhang, and J.M. Song, Toxicological evaluation of fucoidan extracted from Laminaria japonica in Wistar rats, Food Chemistry and Toxicology., Vol. 43, pp. 421-426, 2005.

[108] M.S. Pereira, B. Mulloy, and P.A.S. Mourao, Structure and anticoagulant activity of sulfated fucans. Comparison between the regular, repetitive, and linear fucans from echinoderms with the more heterogeneous and branched polymers from brown algae, Journal of Biological Chemistry., Vol. 274, pp. 7656-7667, 1999.

[109] V. Grauffel, B. Kloareg, S. Mabeau, P. Durand, and J. Jozefonvicz, New natural polysaccharides with potent antithrombotic activity: Fucans from brown algae, Biomaterials., Vol. 10, pp. 363-368, 1989.

[110] T.A. Kuznetsova, N.N. Besednova, A.N. Mamaev, A.P. Momot, N.M. Shevchenko, and T.N. Zvyagintseva, Anticoagulant activity of fucoidan from brown algae Fucus evanescens of the Okhotsk Sea, Bulletin of Experimental Biology and Medicine., Vol. 136, pp. 471-473, 2003.

[111] S. Mauray, C. Sternberg, J. Theveniaux, J. Millet, C. Sinquin, J. Tapon-Bretaudiere, and A.M. Fischer, Venous antithrombotic and anticoagulant activities of a fucoidan fraction. Thrombosis and Haemostasis., Vol. 74, pp. 1280-1285, 1995.

[112] A. Cumashi, N.A. Ushakova, M.E. Preobrazhenskaya, A. D'Incecco, A. Piccoli, L. Totani, N. Tinari, G.E. Morozevich, A.E. Berman, M.I. Bilan, A.I. Usov, N.E. Ustyuzhanina, A.A. Grachev, C.J. Sanderson, M. Kelly, G.A. Rabinovich, S. Iacobelli, and N.E. Nifantiev, A comparative study of the anti-inflammatory, anticoagulant, antiangiogenic, and antiadhesive activities of nine different fucoidans from brown seaweeds, Glycobiology., Vol. 17, pp. 541-552, 2007.

[113] T. Nishino, G. Yokoyama, K. Dobashi, M. Fujihara, and T. Nagumo, Isolation, purification, and characterization of fucose-containing sulfated polysaccharides from the brown seaweed Ecklonia kurome and their blood-anticoagulant activities, Carbohydrate Research., Vol. 186, pp. 119-129, 1989. 
[114] T. Nishino, and T. Nagumo, The sulfate-content dependence of the anticoagulant activity of a fucan sulfate from the brown seaweed Ecklonia kurome, Carbohydrate Research., Vol. 214, pp. 193-197, 1991.

[115] V.H. Pomin, M.S. Pereira, A.P. Valente, D.M. Tollefsen, M.S.G. Pavao, and P.A.S. Mourao, Selective cleavage and anticoagulant activity of a sulfated fucan: Stereospecific removal of a 2-sulfate ester from the polysaccharide by mild acid hydrolysis, preparation of oligosaccharides, and heparin cofactor II-dependent anticoagulant activity, Glycobiology., Vol. 15, pp. 369-381, 2005.

[116] T. Nishino, and T. Nagumo, Anticoagulant and antithrombin activities of oversulfated fucans, Carbohydrate Research.,Vol. 229, pp. 355-362, 1992.

[117] K. Matsubara, Y. Matsuura, A. Bacic, M.L. Liao, K. Hori, and K. Miyazawa, Anticoagulant properties of a sulfated galactan preparation from a marine green alga, Codium cylindricum, International Journal of Biological Macromolecules., Vol. 28, pp. 395-399, 2001.

[118] E.H.C. Farias, V.H. Pomin, A.P. Valente, H.B.O. Nader, H.A. Rocha, and P.A.S. Mourao, A preponderantly 4-sulfated, 3-linked galactan from the green alga Codium isthmocladum, Glycobiology., Vol. 18, pp. 250-259, 2008.

[119] W. Mao, X. Zang, , Y. Li, and H. Zhang, Sulfated polysaccharides from marine green algae Ulva conglobata and their anticoagulant activity, Journal of Applied Phycology., Vol. 18, pp. 9-14, 2006.

[120] Y. Hayakawa, T. Hayashi, J.B. Lee, P. Srisomporn, M. Maeda, T. Ozawa, and N. Sakuragawa, Inhibition of thrombin by sulfated polysaccharides isolated from green algae. Biochimica Biophysica Acta., Vol. 1543, pp. 86-94, 2000.

[121] W.R.L. Farias, A.P. Valente, M.S. Pereira, and P.A.S. Mourao, Structure and anticoagulant activity of sulfated galactans. Isolation of a unique sulfated galactan from the red algae Botryocladia occidentalis and comparison of its anticoagulant action with that of sulfated galactans from invertebrates, Journal of Biological Chemistry., Vol. 275, pp. 2929929307, 2000.

[122] B.F. Glauser, R.M. Rezende, F.R. Melo, M.S. Pereira, I.M.B. Francischetti, R.Q. Monteiro, A.R. Rezaie, and P.A.S. Mourao, Anticoagulant activity of a sulfated galactan: Serpin-independent effect and specific interaction with factor Xa, Thrombiosis and Haemostasis., Vol. 102, pp. 1183-1193, 2009.

[123] M.G. Pereira, N.M.B. Benevides, M.R.S. Melo, A.P. Valente, F.R. Melo, and P.A.S. Mourao, Structure and anticoagulant activity of a sulfated galactan from the red alga, Gelidium crinale. Is there a specific structural requirement for the anticoagulant action? Carbohydrate Research., Vol. 340, pp. 2015-2023, 2005.

[124] P.A.S. Mourao, and M.S. Pereira, Searching for alternatives to heparin: Sulfated fucans from marine invertebrates, Trends in Cardiovascular Medicine., Vol. 9, pp. 225-232, 1999.

[125] J.A. Anderson, J.C. Fredenburgh, A.R. Stafford, Y.S. Guo, J. Hirsh, V. Ghazarossian, and J.I. Weitz, Hyper Sulfated low molecular weight heparin with reduced affinity for antithrombin acts as an anticoagulant by inhibiting intrinsic tenase and prothrombinase, Journal of Biological Chemistry., Vol. 276, pp. 9755-9761, 2001.

[126] C. Barrow, and F. Shahidi, Marine nutraceuticals and functional foods. New York, USA: CRC Press, Taylor and Francis group, New York, pp. 23-61, 2008.

[127] J. Millet, S.C. Jouault, S. Mauray, J. Theveniaux, C. Sternberg, C.B. Vidal, and A.M. Fischer, Antithrombotic and anticoagulant activities of a low molecular weight fucoidan by the subcutaneous route, Thrombosis and Haemostasis., Vol. 81, pp.391-395, 1999. 
[128] C. Boisson-Vidal, F. Chaubet, L. Chevolot, C. Sinquin, J. Theveniaux, J. Millet, C. Sternberg, B. Mulloy, and A.M. Fischer, Relationship between antithrombotic activities of fucans and their structure, Drug Development Research., Vol.51, pp. 216-224.

[129] W.W. Hawkins, V.G. Leonard, J.E. Maxwell, and K.S. Rastogi, A study of the prolonged intake of small amounts of EDTA on the utilization of low dietary levels of calcium and iron by the rat, Canadian Journal of Biochemistry and Physiology., Vol. 40, pp. 391-395, 1962.

[130] W.W. Hawkins, and V.G. Leonard, Antithrombic Activity of Carrageenin in Human Blood, Canadian Journal of Biochemistry and Physiology., Vol. 41, pp. 1325-1327, 1963.

[131] G. Kindness, F.B. Williamson, and W.F. Long, Effect of polyanetholesulphonic acid and xylan sulphate on antithrombin III activity, Biochemical and Biophysical Research Communication., Vol.13, pp. 1062-1068, 1979.

[132] A.K. Sen, A.K. Das, N. Banerji, A.K. Siddhanta, K.H. Mody, B.K. Ramavat, V.D. Chauhan, J.R. Vedasiromoni, and D.K. Ganguly, A new sulfated polysaccharide with potent blood anti-coagulant activity from the red seaweed Grateloupia Indica, International Journal of Biological Macromolecules., Vol.16, pp. 279- 280, 1994.

[133] D. Chen, X.Z. Wu, and Z.Y. Wen, Sulfated polysaccharides and immune response: promoter or inhibitor? Panminerva Medica., Vol. 50, pp. 177-183, 2008.

[134] C. Granert, J. Raud, X. Xie, L. Lindquist, and L. Lindbom, Inhibition of leukocyte rolling with polysaccharide fucoidan prevents pleocytosis in experimental meningitis in the rabbit, Journal of Clinical Investigation., Vol. 93, pp. 929-936, 1994.

[135] M.E. Preobrazhenskaya, A.E. Berman, V.I. Mikhailov, N.A. Ushakova, A.V. Mazurov, A.V. Semenov, A.I. Usov, N.E. Nifant'ev, and N.V. Bovin, Fucoidan inhibits leukocyte recruitment in a model peritoneal inflammation in rat and blocks interaction of P-selectin with its carbohydrate ligand, Biochemistry and Molecular Biology International., Vol. 43, pp. 443-451, 1997.

[136] M. VerVerdrengh, H. Erlandsson-Harris, and A. Tarkowski, Role of selectins in experimental Staphylococcus aureus-induced arthritis, European Journal of Immunology., Vol. 30, pp. 1606-1613, 2000.

[137] T. Nasu, Y. Fukuda, K. Nagahira, H. Kawashima, C. Noguchi, and T. Nakanishi, Fucoidan, a potent inhibitor of L-selectin function, reduces contact hypersensitivity reaction in mice, Immunology Letters., Vol. 59, pp. 47-51, 1997.

[138] C. Ostergaard, R.V. Yieng-Kow, T. Benfield, N. Frimodt-Moller, F. Espersen, and J.D. Lundgren, Inhibition of leukocyte entry into the brain by the selectin blocker fucoidan decreases interleukin-1 (IL-1) levels but increases IL-8 levels in cerebrospinal fluid during experimental pneumococcal meningitis in rabbits, Infection Immunology., Vol. 68, pp. 31533157, 2000.

[139] K. Senni, F. Gueniche, A. Foucault-Bertaud, S. Igondjo-Tchen, F. Fioretti, S. ColliecJouault, P. Durand, J. Guezennec, G. Godeau, and D. Letourneur, Fucoidan a sulfated polysaccharide from brown algae is a potent modulator of connective tissue proteolysis, Archives of Biochemistry and Biophysics., Vol. 445, pp. 56-64, 2006.

[140] C.R. Parish, C. Freeman, and M.D. Hulett, Heparanase: a key enzyme involved in cell invasion, Biochimica et Biophysica Acta., Vol. 1471, pp. 99-108, 2001.

[141] C. Blondin, E. Fischer, C. Boisson-Vidal, M.D. Kazatchkine, and J. Jozefonvicz, Inhibition of complement activation by natural sulfated polysaccharides (fucans) from brown seaweed, Molecular Immunology., Vol. 31, pp. 247-253, 1994. 
[142] B. Tissot, B. Montdargent, L. Chevolot, A. Varenne, S. Descroix, P. Gareil, R. Daniel, Interaction of fucoidan with the proteins of the complement classical pathway, Biochimica et Biophysica Acta., Vol. 1651, pp. 5-16, 2003.

[143] B. Tissot, F. Gonnet, A. Iborra, C. Berthou, N. Thielens, G.J. Arlaud, and R. Daniel, Mass spectrometry analysis of the oligomeric $\mathrm{C} 1 \mathrm{q}$ protein reveals the $\mathrm{B}$ chain as the target of trypsin cleavage and interaction with fucoidan, Biochemistry., Vol. 44, pp. 2602-2609, 2005. [144] M.J. Clement, B. Tissot, L. Chevolot, E. Adjadj, Y. Du, P.A. Curmi, and R. Daniel, NMR characterization and molecular modeling of fucoidan showing the importance of oligosaccharide branching in its anticomplementary activity, Glycobiology., Vol. 20, pp. 883-894, 2010.

[145] R.F. Tsuji, K. Hoshino, Y. Noro, N.M. Tsuji, T. Kurokawa, T. Masuda, S. Akira, B. Nowak, Suppression of allergic reaction by lambda-carrageenan: Toll-like receptor 4/MyD88-dependent and -independent modulation of immunity. Clinical and Experimental Allergy., Vol. 33, pp. 249-258, 2003.

[146] H. Maruyama, H. Tamauchi, M. Hashimoto, and T. Nakano, Suppression of Th2 immune responses by mekabu fucoidan from Undaria pinnatifida sporophylls, International Archives of Allergy and Immunology., Vol. 137, pp. 289-294, 2005.

[147] A.I. Usov, Structural analysis of laminarans by MALDI and FAB mass spectrometry, Carbohydrate Research., Vol. 310, pp. 203-210, 1998.

[148] L. Hayashi, N.S. Yokoya, S. Ostini, R.T.L. Pereira, E.S. Braga, and E.C. Oliveira, Nutrients removed by Kappaphycus alvarezii (Rhodophyta, Solieriaceae) in integrated cultivation with fishes in recirculating water, Aquaculture., Vol. 277, pp. 185-191, 2008.

[149] W.T. Wang, J.H. Zhou, and S.T. Xing, Immunomodulating action of marine algae sulfated polysaccharides on normal and immunosuppressed mice. Chinese Journal of Pharmacology and Toxicology, Vol. 8, pp. 199-202, 1994.

[150] X.W. Wu, M.L. Yang, X.L. Huang, J. Yan, and Q. Luo, Effect of fucoidan on splenic lymphocyte apoptosis induced by radiation, China Journal of radiology and Medical Protection., Vol. 23, pp. 430-432, 2003.

[151] X.L. Yang, J.Y. Sun, and H.N. Xu, An experimental study on immunoregulatory effect of fucoidan, China Journal of Marine Drugs.,Vol. 14, pp. 9-13, 1995.

[152] J.M. Leiro, R. Castro, J.A. Arranz, and J. Lamas, Immunomodulating activities of acidic sulphated polysaccharides obtained from the seaweed Ulva rigida C. Agardh, International Immunopharmacology., Vol. 7, pp. 879-888, 2007.

[153] T. Nakamura, H. Suzuki, Y. Wada, T .Kodama, and T. Doi, Fucoidan induces nitric oxide production via p38 mitogen-activated protein kinase and NF-kB-dependent signaling pathways through macrophage scavenger receptors, Biochemical and Biophysical Research Communication., Vol. 343, pp. 286-294, 2006.

[154] J.W. Yang, S.Y. Yoon, S.J.Oh S.K. Kim, and K.W. Kang, Bifunctional effects of fucoidan on the expression of inducible nitric oxide synthase, Biochemical and Biophysical Research Communication, Vol. 346, pp. 345-350, 2006.

[155] H. Do, S. Pyo, and E.H. Sohn, Suppression of iNOS expression by fucoidan is mediated by regulation of p38 MAPK, JAK/STAT, AP-1 and IRF-1, and depends on upregulation of scavenger receptor B1 expression in TNF-alpha- and IFN-gamma-stimulated C6 glioma cells, Journal of Nutritional Biochemistry., Vol. 21, pp. 671, 2010.

[156] E.M. Choi, A.J. Kim, Y.O. Kim, and J.K. Hwang, Immunomodulating activity of arabinogalactan and fucoidan in vitro, Journal of Medicinal Food., Vol. 8, pp. 446-453, 2005. 
[157] M. Lahaye, Marine-algae as sources of fibers - determination of soluble and insoluble dietary fiber contents in some sea vegetables, Journal of Science Food Agriculture, Vol. 54, pp. 587-594, 1991.

[158] N, Fleury and M. Lahaye, Chemical and physicochemical characterization of fibers from Laminaria digitata (Kombu Breton) - A physiological approach, Journal of Science Food Agriculture, Vol. 55, pp. 389-400, 1991.

[159] D.J. McHugh, A guide to the seaweed industry', FAO Fisheries Technical Paper, no. 441, Rome, 2003.

[160] H. Amano, M. Kakinuma, D.A. Coury, H. Ohno, and T. Hara, Effect of a seaweed mixture on serum lipid level and platelet aggregation in rats, Fisheries Science., Vol. 71, pp. 1160- 1166, 2005.

[161] Y. Athukorala, K.W. Lee, S.K. Kim, Y.J. Jeon, Anticoagulant activity of marine green and brown algae collected from Jeju Island in Korea, Bioresource Technology., Vol. 98, pp. 1711-1716, 2007.

[162] H. Ye, K. Wang, C. Zhou, J. Liu, and X. Zeng, Purification, antitumor and antioxidant activities in vitro of polysaccharides from the brown seaweed Sargassum pallidum. Food Chemistry., Vol.111, pp. 428-432, 2008.

[163] D.J.A. Jenkins, T.M.S. Wolever, A.R. Leeds, M.A. Gassull, P. Haisman, J.,Dilawari, D.V. Goff, G.L. Metz, and K.G. Alberti, Dietary fibers, fiber analogs, and glucose-tolerance importance of viscosity, British Medicine Journal, Vol. 1, pp. 1392-1394, 1978.

[164] S. Mabeau , and J. Fleurence, Seaweed in food products: biochemical and nutritional aspects, Trends in Food Science and Technology., Vol. 4, pp. 103-107. 1993.

[165] P. Laurienzo, Marine Polysaccharides in Pharmaceutical Applications: An Overview, Marine Drugs., Vol. 8, pp. 2435-2465, 2010.

[166] C. Bodin-Dubigeon, M. Lahaye, and J.L. Barry, Human colonic bacterial degradability of dietary fibres from sea lettuce (Ulva sp.), Journal of Science Food and Agriculture., Vol. 73, pp. 149-159, 1997.

[167] H.J. Bixler, Recent developments in manufacturing and marketing carrageenan, Hydrobiologia., Vol. 326, pp. 35-57, 1996.

[168] Y. De Roeck -Holtzhauer, Uses of seaweed in cosmetics. In: Guiry MD, Blunden G (eds) Seaweed resources in Europe: uses and potential. Wiley, Chichester, pp.83-94, 1991.

[169] M. Knauf, and M. Moniruzzaman, Lignocellulosic biomass processing: a perspective, International Sugar Journal., Vol. 106, pp. 147-150, 2004.

170] P. Burtin, Nutritional value of seaweeds, Electronic Journal of Environmental Agriculture and Food Chemistry., Vol. 2, pp. 498-503, 2003.

[171] K. Ito, and Y. Tsuchida, The effect of algal polysaccharides on depressing of plasma cholesterol level in rats. Proceeding of The Seventh International Seaweed Symposium, pp. 451- 455, 1972.

[172] S. Kiriyama, Y. Okazaki, and A. Yoshida, Hypocholesterolemic effect of polysaccharides and polysaccharide-rich foodstuffs in cholesterol-fed rats, Journal of Nutrition, Vol. 97, pp. 382-388, 1969.

[173] X. Hu, X. Jiang, H. Hwang, S. Liu, and H. Guan, Antitumor activities of alginatederived oligosaccharides and their sulphated substitution derivatives, European Journal of Phycology., Vol. 39, pp. 67-71, 2004.

[174] L.N. Panlasigui, O.Q. Baello, J.M. Dimatangal, and B.D.Dumelod, Blood cholesterol and lipid-lowering effects of carrageenan on human volunteers, Asia Pacific Journal of Clinical Nutrition., Vol. 12, pp. 209-214, 2003.. 
[175] M. Szekalska, A. Puciłowska, E. Szymańska,P. Ciosek, and K. Winnicka, Alginate: Current Use and Future Perspectives in Pharmaceutical and Biomedical Application, International Journal of Polymer Science., Vol. 2016, Article ID 7697031, 2016.

[176] B.D. Dumelod, R.P.B. Ramirez , C.L.P. Tiangson, E.B. Barrios, and L.N. Panlasigui, Carbohydrate availability of arroz caldo with lambda-carrageenan, International Journal of Food Science and Nutrition., Vol.50, pp. 283-289, 1999.

[177] E. Nishide, H. Anzai, and N. Uchida, Effects of alginates on the ingestion and excretion of cholesterol in the rat, Journal of Applied Phycology., Vol. 5, pp. 207-211, 1993. [178] Y. Kimura, K. Watanabe, and H. Okuda, Effects of soluble sodium alginate on cholesterol excretion and glucose tolerance in rats, Journal of Ethnopharmacology., Vol. 54, pp. 47-54, 1996.

[179] S. Zee, Body weight loss with the aid of alginic acid. Archives of International Medicine.,Vol. 3-4, pp.113-114, 1991.

[180] I. Torsdottir, M. Alpsten, G. Holm, A.S. Sandberg, and J. Tolli, A small dose of soluble alginate-fiber affects postprandial glycemia and gastric-emptying in humans with diabetes, Journal of Nutrition., Vol. 121, pp. 795-799, 1991.

[181] P. Vaugelade, C. Hoebler, F. Bernard, F. Guillon, M. Lahaye, P. Duee, and B. DarcyVrillon, Non-starch polysaccharides extracted from seaweed can modulate intestinal absorption of glucose and insulin response in the pig. Reproduction Nutrition Development., Vol. 1, pp. 33-47, 2000.

[182] C.B. Bogentoff, Antacid composition of neutralizing stomach acid. Germany patent 2,722,984, 1981.

[183] E. Borgo, Pharmaceutical composition for the treatment of gastric hyperacidity, gastritis and gastroduodenal ulcers, Canada patent, 1,176984, 1984.

[184] B.B. Sheth, Alginate containing antacid compositions. US patent 3,326755, 1967.

[185] Y.S. Khotimchenko, V.V. Kovalev, U.V. Savchenko, and O.A. Ziganshina, Physicalchemical properties, physiological activity, and usage of alginates, the polysaccharides of brown algae, Russian Journal of Marine Biology, Vol. 27, pp. 53-64, 2001.

[186] N. Washington, and G. Denton, Effect of alginate and alginate-cimetidine combination therapy on stimulated postprandial gastro-oesophageal reflux, Journal of Pharmacy and Pharmacology.,Vol. 47, pp. 879-882, 1995.

[187] I.M. Savitskaya, Trial of a local hemostatic with alginate base, Klin Khirurgiya., Vol. 3, pp. 39-40, 1986.

[188] H.C. Segal, B.J. Hunt, and K. Gilding, The effects of alginate and non-alginate wound dressings on blood coagulation and platelet activation, Journal of Biomaterial Applications., Vol. 12, pp. 249-257, 1998.

[189] S. Katayama, J. Ohshita, K. Sugaya, M. Hirano, Y. Momose, and S. Yamamura, New medicinal treatment for severe gingivostomatitis, International Journal of Molecular Medicine., Vol. 2, pp. 675-679, 1998.

[190] J.E.F. Reynolds, and A.B. Prasad, Martindale the extra pharmacopoeia. 28th Pharmaceutical Press, London, pp.735, 1982.

[191] H. Chen, M. Zhang, and X .Bijun, Components and antioxidant activity of polysaccharide conjugate from green tea, Food Chemistry., Vol. 90, pp. 17-21, 2005.

[192] L.E. Fernandez, O.G. Valiente, V. Mainardi, J.L. Bello, H. Velez, and A. Rosado, Isolation and characterization of an antitumor active agar-type polysaccharide of Gracilaria dominguensis, Carbohydrate Research., Vol. 190, pp. 77-83, 1989. 
[193] A. Mouradi-Givernaud, T. Givernaud, H. Morvan, and J. Cosson, Agar from Gelidium latifolium (Rhodophyceae, Gelidiales)- biochemical composition and seasonal variations, Botanica Marina., Vol. 35, pp. 153-59, 1992.

[194] S. Prajapati, L. Patel, A. Patel, Carrageenan:A Naturally Occurring Routinely Used Excipient, Pharmaceutical Reviews., Vol. 5, 2007.

[195] R.C. Rowe, P.J.Sheskey, and P.J.Weller, Handbook of pharmaceutical excipients,pharmaceutical Press, London, 2007. 